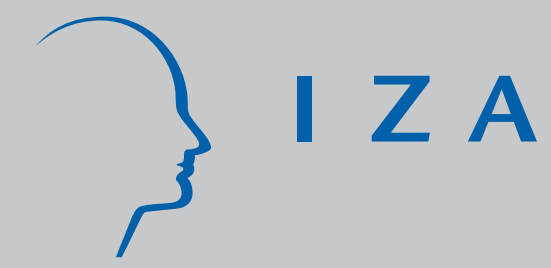

IZA DP No. 89

Aliyah to Israel: Immigration under Conditions of Adversity

Shoshana Neuman

December 1999 


\title{
ALIYAH TO ISRAEL: IMMIGRATION UNDER CONDITIONS OF ADVERSITY
}

\author{
Shoshana Neuman \\ Bar-Ilan University, Israel
}

\section{Discussion Paper No. 89 \\ December 1999}

\author{
IZA \\ P.O. Box 7240 \\ D-53072 Bonn \\ Germany \\ Tel.: +49-228-3894-0 \\ Fax: +49-228-3894-210 \\ Email: iza@iza.org
}

This Discussion Paper is issued within the framework of IZA's research area Mobility and Flexibility of Labor Markets. Any opinions expressed here are those of the author(s) and not those of the institute. Research disseminated by IZA may include views on policy, but the institute itself takes no institutional policy positions.

The Institute for the Study of Labor (IZA) in Bonn is a local and virtual international research center and a place of communication between science, politics and business. IZA is an independent, nonprofit limited liability company (Gesellschaft mit beschränkter Haftung) supported by the Deutsche Post AG. The center is associated with the University of Bonn and offers a stimulating research environment through its research networks, research support, and visitors and doctoral programs. IZA engages in (i) original and internationally competitive research in all fields of labor economics, (ii) development of policy concepts, and (iii) dissemination of research results and concepts to the interested public. The current research program deals with (1) mobility and flexibility of labor markets, (2) internationalization of labor markets and European integration, (3) the welfare state and labor markets, (4) labor markets in transition, (5) the future of work, (6) project evaluation and (7) general labor economics.

IZA Discussion Papers often represent preliminary work and are circulated to encourage discussion. Citation of such a paper should account for its provisional character. 
IZA Discussion Paper No. 89

December 1999

\section{ABSTRACT}

\section{ALIYAH TO ISRAEL: IMMIGRATION UNDER CONDITIONS OF ADVERSITY}

A snapshot at figures of immigration (Aliyah) to the Land of Israel (Palestine) and to the State of Israel reveals the following: between 1882-1947, in successive waves of immigration, some 543,000 Jews immigrated to Palestine, joining the 24,000 who lived there. During the first three years of statehood (1948-1950) the average annual growth rate of the Jewish population was about 24 percent, and between 1948-1952, mass immigration of 711,000 supplemented a population of 630,000 . Recently, Israel witnessed a massive influx of Soviet immigrants. During 1990-1998 the Israeli population of 4.56 million was enriched by 879,486 immigrants, a growth rate of 19.3 percent. In 1991, 15,000 Jews were airlifted in one single day in "Operation Solomon".

What were the factors that drove this unprecedented migration of Jews from around the globe to Israel? Many of the major international migration movements were largely economic in nature (the push of poverty or the pull of expected enhanced standards of living) or have been in response to persecution. While all these factors have played some role in immigration to Israel, the Israeli case is unusual in that its origins are essentially ideological. Israel has always encouraged and assisted the immigration and absorption process as part of a pro-immigration ideology and policy. Its raison d'être was and remains the ingathering and retention of Jewish immigrants and the forging of these diverse elements into a unified nation. Israel is a country established for and administered by immigrants from diverse countries and origins.

In most cases of rapid population growth, per capita income declines. This is due to adjustment problems, low productivity of immigrants and infrastructure bottle-necks. Israel was an exception. Immigration was accompanied by accelerated growth rates even though large public funds were devoted to housing, employment and social services to facilitate the direct absorption of mass immigration. As a result, per capita income which was $\$ 3,500$ in 1950 surged to $\$ 17,000$ in 1996 - an annual growth rate of 3.5 percent.

This paper describes the major waves of immigration to Israel, starting from 1882 up to the present. For each immigration wave, its size, composition, origin and characteristics are documented.

It then focuses on the process of immigrants' assimilation in the local labor market and addresses three main questions: (i) How well do immigrants adapt to the Israeli economy? (ii) What are the effects of immigration on employment opportunities and are they paying their way in the welfare state? (iii) Are population and production growth interrelated?

The facts and figures lead to an overall evaluation of the immigration process and to the lessons to be learned from past experience to improve the absorption process. In particular, return migration, which reflects failure to absorb, is discussed, and the very different absorption policies of the 1950s and the 1990s are contrasted and compared. Suggestions for changes in immigration policies are discussed. An evaluation of the contribution of immigration to economic growth and of the importance of Hebrew language acquisition is also presented. The last section of this paper provides a summary and conclusions.

JEL Classification: J15, J61

Keywords: Migration, migration policy

Shoshana Neuman

Department of Economics

Bar-Ilan University

52900 Ramat-Gan

Israel

Tel: 972-3-5318393

Fax: 972-3-5353180

Email: neumans@mail.biu.ac.il 


\section{Introduction}

A snapshot at figures of immigration (Aliyah) to the Land of Israel (Palestine) and to the State of Israel, reveals the following: between 1882-1947, in successive waves of immigration, some 543,000 Jews immigrated to Palestine, joining the 24,000 who lived there. During the first three years of statehood (1948-1950) the average annual growth rate of the Jewish population was about 24 percent, and between 1948-1952, mass immigration of 711,000 supplemented a population of 630,000 . Recently, Israel witnessed a massive influx of Soviet immigrants. During 1990-1998 the Israeli population of 4.56 million was enriched by 879,486 immigrants - a growth rate of 19.3 percent. In 1991, 15,000 Jews were airlifted in one single day in "Operation Solomon".

What were the factors that drove this unprecedented migration of Jews from around the globe to Israel? Many of the major international migration movements were largely economic in nature (the push of poverty or the pull of expected enhanced standards of living) or have been in response to persecution. While all these factors have played some role in immigration to Israel, the Israeli case is unusual in that its origins are essentially ideological, triggered by the emergence of the Zionist Movement in Eastern and Central Europe in the last quarter of the nineteenth century. The early immigrants were motivated by a commitment to resettle and rebuild the Land of Israel, neglected by centuries of Jewish dispersal round the world; this was paralleled by the intention to create a new socio-economic order which would reverse the narrow occupational base allowed to Jews in the Diaspora. These ideological motivations were inherited by their successors; while economic and political considerations also played a minor role, the major incentive for immigration remained ideological.

Israel has always encouraged and assisted the immigration and absorption process as part of a pro-immigration ideology and policy. Its raison d'être was and remains the ingathering and retention of Jewish immigrants and the forging of these diverse elements into a unified 
nation. Israel is a country established for and administered by immigrants from diverse countries and origins. The Declaration of the Establishment of the State of Israel (May 14, 1948) states:

The State of Israel will be open to Jewish immigration and after the Ingathering of the Exiles will develop the country for the benefit of all its citizens; will be based on the principles of equality, justice and peace in light of the vision of the prophets; will credit equal social and political right to all its citizens no matter what their religion, race or gender; will ensure rights of religion, consciousness, education, and culture; will keep the religious sites of all religions; and will be faithful to the principles of the United Nations.

Israel is legally committed to the absorption of any applicant of Jewish origin. The "Law

of Return" which was passed in 1950 states that:

...each and every Jew has the right to immigrate to Israel.... He will be given an Immigration Certificate by the Minister of Interior... unless he is: acting against the Jewish people; might endanger the health of the public or the security of the country; or has a criminal record which might endanger the safety of the public.

In 1970 this law was amended and the right to immigrate extended to the children, grandchildren, spouse and spouses of children and grandchildren of a person who is Jewish. A person is defined as Jewish if he has a Jewish mother or had converted to Judaism. ${ }^{1}$ Indeed, the application of the Law of Return resulted in the growth of the Jewish population from 1.37 million in 1950 to 4.86 million at the end of 1998 .

In most cases of rapid population growth, per capita income declines. This is due to adjustment problems, low productivity of immigrants and infrastructure bottle-necks.

\footnotetext{
${ }^{1}$ Immigrants may choose to enter the country on a A-1 visa or as full citizens. The latter have the right to vote, as well as the obligation to serve in the Israeli Defense Forces. Apart from this, there is no difference between the two categories of immigration. For example, entitlement for absorption subsidies is not affected. Normally, A-1 immigrants are expected to become full citizens after three years but may renew their A-1 status, if so desired. Although Israeli law permits dual or multiple nationality, immigrants from certain countries are deprived of their original citizenship on emigrating (e.g., from the USSR) or fleeing from their original country (e.g., from Iran). In those cases they are required to become full Israeli citizens and thus the A-1 visa is not an option. Non-Jews, too, may immigrate, but in common with international practice, this right is restricted (Beenstock, 1993).
} 
Israel was an exception. Immigration was accompanied by accelerated growth rates even though large public funds were devoted to housing, employment and social services to facilitate the direct absorption of mass immigration. As a result, per capita income which was $\$ 3,500$ in 1950 surged to $\$ 17,000$ in 1996 - an annual growth rate of 3.5 percent. $^{2}$ Israel now comes close to the per capital GDP of the high-income economies and is well above the figures of the middle-income economies (World Bank, 1995). As an illustration, in 1950 per capita income (adjusted to purchasing power) in the US was 260 percent larger than in Israel. In 1995 the difference shrank to 65 percent. Comparing Britain and Israel, a difference of 114 percent in 1950 dropped to 15 percent in 1995 . There is no parallel in economic history of rapid economic growth going hand in hand with massive immigration and population growth.

While Jewish immigration and the establishment of the State of Israel created the opportunity to achieve the Zionist Movement's goals, it also intensified the historical JewishArab conflict. As the Jewish community grew, conflict with the Arab population escalated. When independence was declared, the new state was already engaged in the first of a series of wars (others following in 1956, 1967, 1970, 1973 and 1982) with neighboring Arab countries. The War of Independence established the borders of the new state and led to the departure of a significant portion of the Arab population.

At the end of 1997, the Israeli population of 5.9 million was composed of 4.7 million Jews (80 percent), 868 thousand Moslems (15 percent), 126 thousand Christians (2 percent) and 97 thousand Druze (close to 2 percent). About 108 thousand were not classified by religion.

While millions of Jews left their country of origin to settle in Israel, at the end of 1995 only 34.8 percent of world Jewry live in Israel and some 8.5 million still reside all over the

2 Growth rates varied during the period 1950-1996; from 5 percent in the 1950s and 1960s, they declined to 2 percent in the $1970 \mathrm{~s}$ and $1980 \mathrm{~s}$ and then increased a little to 2.5 percent in the $1990 \mathrm{~s}$. 
world. The largest Jewish community lives in the United States (5.69 million, 43.6 percent of world Jewish population). Other major countries of residence, with more than 100,000 Jewish residents are the former USSR (660,000; 5.3 percent), France $(525,000 ; 4$ percent), Canada $(362,000 ; 2.8$ percent), the United Kingdom (292, 000; 2.2 percent), Argentina (206,000; 1.6 percent) and Brazil (100,000, 0.8 percent) (Della Pergola, 1997).

There is a strong and lasting relationship between Israel and Jews worldwide. These ties translate into material as well as moral support and thus carry concrete implications for the availability of national resources and the balance of payments. Transfers from World Jewry have been a major source of external financing. This aid, which is especially responsive in times of emergencies, provides a unique economic safety net.

The present chapter is organized as follows: the following section describes the major waves of immigration, starting from 1882 up to the present. For each immigration wave, its size, composition, origin and characteristics are documented.

The third focuses on the process of immigrants' assimilation in the local labor market and addresses three main questions: How well do immigrants adapt to the Israeli economy?, What are the effects of immigration on employment opportunities and are they paying their way in the welfare state? and, Are population and production growth interrelated?

The fourth section attempts an overall evaluation of the immigration process and considers what may be learned from past experience to improve the absorption process. In particular, return migration, which reflects failure to absorb, is discussed and the very different absorption policies of the 1950s and the 1990s are contrasted and compared. Suggestions for changes in immigration policies are discussed. An evaluation of the contribution of immigration to economic growth and of the importance of Hebrew language acquisition conclude the section. The last section provides a summary and conclusions. 


\section{Jewish Immigration to Israel: Facts and Policies}

The Land of Israel (Palestine) was under foreign occupation for many centuries. Between 1517 and 1917 it was under Ottoman rule. The British occupation, which began in 1917, became a British mandate in 1924. In November 1947 the UN Partition Resolution was accepted by a majority vote, and the State of Israel was established on May 14, 1948.

Jewish immigration to Palestine began in the last quarter of the nineteenth century, accelerated in 1882 after the emergence of the Zionist Movement and has continued ever since. The period 1882-1996 can be decomposed into five subperiods: 1882-14.5.1948, 15.5.1948-1951, 1952-1966, 1967-1989 and 1990-1998.

\section{Immigration Streams: Size, Origin and Dispersal}

Table 1 presents Jewish immigration figures for each of the subperiods, as well as the average annual number of Jewish newcomers and their contribution to population growth. Table 2 looks at two other sources of population growth as well: fertility and emigration. It also documents the share of net migration (immigration minus outmigration) out of the total population increase.

\section{Insert table 1 here.}

Table 1 reveals that in each of the five periods, more than half a million Jewish immigrants arrived in the country. Dividing the numbers relating to the totals by the different time spans yields annual figures. The most impressive average belongs to the first three and a half years after statehood - 199,244 immigrants settled in Israel per year, adding each year 22.7 percent to the Jewish population. Second comes the most recent wave of immigrants who came, predominantly, from the former Soviet Union - 97,721 newcomers arrived every year, thereby causing a population growth at an annual rate of 2.5 percent. Immigration was more moderate during 1952-1966 and 1967-1989. During the 1952-1966 period immigration 
was responsible for an annual increase of population by the size of 2.4 percent and this figure dropped to only 0.9 percent during 1967-1989. Before statehood the annual number of immigrants was relatively low $-8,293$. However, as the Jewish population at the beginning of this period numbered only 24,000 , immigration led to an annual growth rate of 4.9 percent.

\section{Insert table 2 here.}

Table 2 provides a closer look at population growth and immigration after statehood. Considering the entire time period (15.5.1948 - end of 1996, detailed data for 1997/8 has not yet been published), we see that the Jewish population grew at an annual rate of 4.1 percent and net migration was responsible for 49.6 percent of population growth rates. More than two and a half million Jews immigrated to Israel and half a million (both former immigrants and natives) outmigrated.

Major differences in immigration measures, in the different subperiods, result in differences in population growth rates and in the share of migration out of total population growth. Immediately following statehood (1948-1951), mass immigration led to an annual growth rate of 23.7 and net immigration accounted for 88.3 percent of total population growth. Shortly after (1952-1966) these figures dropped respectively to 3.5 percent and a share of 46 percent. The decline continued and during 1967-1989 annual growth rates fell to 2 percent and emigration was responsible for only 22.9 percent of total population growth. A dramatic change in this trend has been observed since 1990 - population grows at an annual rate of 3.2 and net migration now explains 62.5 percent of population increase.

The Arab population, which totaled 156,000 in 1948 , grew mainly as a result of natural growth, at an annual rate of 4.3 percent. Only 9.1 percent of total growth stems from migration flows. 
Now that we have had a general overview of population and immigration trends, a closer examination of each of the subperiods will lead to a better understanding of immigration patterns.

\section{Period I: 1882-May 14, 1948}

In 1882 the Jewish population in Palestine which numbered 24,000 was concentrated in four cities:, Hebron, Jerusalem, Safed and Tiberias. The Jewish community shared the land with about one million Arab inhabitants. The land was therefore very sparsely populated and based mainly on subsistence agriculture. At the end of the British Mandate (May 14, 1948) Jewish inhabitants in Palestine numbered 649,500 and composed about one-third of the total population of 1.950 million. They lived in six cities, 22 smaller urban settlements and 302 agricultural settlements. (Bein, 1976). Many of the Jewish settlers were members of the Zionist Movement which emerged in Eastern Europe at the end of the nineteenth century with the goal of resettling the Jewish people in Palestine.

\section{Insert table 3 here.}

The immigrants arrived in five waves of immigration. Table 3 documents their sizes. Each wave had its particular characteristics and influence on the settlements and population. In general, the first three waves (1882-1903, 1904-1914, 1919-1923) known respectively as the First, Second and Third Aliyah (immigration) originated mainly from Russia, Rumania and Poland, following the Russian pogroms of 1881 and the organization of new social movements. Each wave numbered some 35 thousand immigrants who established new types of agricultural settlements, such as the Moshava (private agricultural settlement) and the Moshav and Kibbutz (both collective agricultural settlements).

In contrast, the 82,000 newcomers from the fourth (1924-1931) wave and the 217,000 newcomers from the fifth (1932-1938) wave of immigration, who came from Poland and 
Germany in the wake of World War II and the Holocaust, contributed significantly to the development of the cities in the center of the country (Eisenstadt, 1973). These immigrants imported capital, human capital and socio-economic modernity into the country, helping toward its rapid development and modernization, particularly after the 1930s. They preferred the urban centers of the country as they were the locations of employment and finance (Eisenstadt, 1967, 1973). Many of the country's political leaders and high-ranking officials, at that time, after statehood, and even today, belong to this wave of immigration.

During Word War II (1939-1945) about 92,000 Jewish immigrants entered the country, many illegally, as the British Mandate restricted the total number of immigrants to 75,000 over five years (The White Paper, May 17, 1939). This was done in a period when immigration to Israel was, for many European Jews, the only means to escape the Holocaust and its aftermath.

After World War II, 61,000 Jews entered the country. The restrictions of the White Paper were still valid and many of the immigrant ships were seized at sea by the British Navy and the passengers were deported to refugee camps in Cyprus. The obstruction of landing in Israel to immigrants who survived the Nazi concentration camps and their internment in refugee camps aroused anger and residence among the Jewish population in Palestine. The British government appealed to the UN for help in solving the problem. In the summer of 1947 a UN committee visited Palestine and, based on its recommendations, the UN Partition Resolution of November 1947 was passed. It gave the Jewish people national rights over parts of Mandatory Palestine.

In 1947 about 80 percent of the Jewish population in Palestine lived in the three capital cities: more than half of the population lived in Tel-Aviv (founded in 1909), about 20 percent in Haifa and close to 10 percent in Jerusalem. At the same time 20 percent inhabited 260 agricultural settlements. Sixty percent of these settlements were located at the geographical 
periphery of Israel (Lipshitz, 1991). The great majority of Jews were of European origin as the number of immigrants from oriental countries was very small during this period.

The funds devoted to immigration and to the development of the Jewish community in Palestine came from Jewish organizations from outside the country. They collected and distributed them, and controlled the absorption process and land acquisition. The chief organization was the World Zionist Movement, replaced in 1929 by the Jewish Agency. The Keren-Kayemet, a second organization closely related to the Jewish Agency, was responsible for land acquisition and bought land for Jewish settlements. Land purchase and agricultural settlements were at the core of Zionist policies and about 40 percent of all expenses were devoted to this purpose. The British Mandate authorized the Zionist Movement, and later the Jewish Agency, as the main representative of the Jewish interests in Palestine (Bein, 1976).

\section{Period II: May 15, 1948-1951}

The establishment of the State of Israel on May 14, 1948 created a major fundamental change in immigration policies. While during the Ottoman and British rule the size of immigration and land acquisition were dictated by the foreign administrations and in many cases tough restrictions were imposed on immigration, this changed altogether. The Israeli government declared its ultimate goal to be the development of the country, aimed at the absorption of a huge wave of immigration. The gates of the nascent country opened widely and the goal of "Ingathering of the Exiles" was declared as the mission of the state. Such a mission was unprecedented in the history of the Jewish nation and even in that of other nations. Moreover, it began while war against Israel was declared by the neighboring Arab countries and was executed by an inexperienced administration with restricted resources which took upon itself the two huge tasks of winning the war and absorbing the many newcomers who fled into the country. 
This immigration wave, which began on May 15,1948, differed from the previous ones in size and composition. 1) Size: Between May 1948 and August 1951 the monthly number of immigrants was $15,000-20,000$. This means that in about three years the Jewish population of 649,500 (on May 14, 1948, at statehood) doubled. At the end of 1951 the Jewish population totaled 1,404,400 which means an annual growth rate of 23.7 percent. 2) Composition. The first to immigrate were Jews who survived the Holocaust and shortly afterwards they were joined by immigrants from Asian and North African countries. Large communities from North Africa, Turkey, Yemen and Iraq left their countries of origin and arrived in Israel. Most of them came for ideological reasons or because they felt insecure in their mother countries. The proportions of immigrants, by continent, were the following: 49 percent from Europe, 35.4 percent from Asia, 15 percent from Africa and 0.6 percent from the Americas and Oceania. ${ }^{3}$ The basic ethnic composition of the Israeli population was formulated at this time. The two major ethnic groups being Westerners (Ashkenazim) - Jews originating from European and American countries and Easterners (Sepharadim) - those who came from Asian and African countries.

The great majority of the immigrants had no capital or property. Their transportation, accommodation and living expenses (at least for the first few months) were covered in part by international Jewish organizations (e.g., the American Joint Committee and the Jewish Agency) and by the Israeli government (Bein, 1976). There also was the urgent need to provide the newcomers with shelter, food, education and social services, and build the infrastructure of administration, defense, health, education and social services. The economic

\footnotetext{
${ }^{3}$ The figures of immigrants (followed by their percentage in parentheses), by country of origin, between May 1948 and the end of 1952 are the following: Eastern Europe: Poland - 106,727 (18). Rumania - 121, 535 (17.6), Bulgaria - 37,703 (5.5) Czechoslovakia - 18, 811 (2.71), Hungary - 14, 517 (2.1) Yugoslavia - 7,737 (1.14 ), other East European countries - 6,171 (0.7); Central and Western Europe: Germany - 8,350 (1.2), France - 3,120 (0.5), Austria- 2,671 (0.4), Italy - 1,321 (0.2), The Netherlands - 1,163 (0.2); Asia: Yemen - 45,127 (6.7), Turkey - 34,647 (5), Iraq - 124,225 (18), Iran - 25,971 (3.8), Syria and Lebanon - 3,162 (0.5), Eden - 3,320 (0.5); Africa: Morocco, Tunisia and Algeria - 52,565 (7.7), Libya - 32,130 (4.6) (Keren-Hayesod, 1953).
} 
burden was very heavy. Funds and loans were provided by the American government, by world Jewry and by the German government (Eban, 1972, pp. 76-82).

The authorities which provided the immigrants with low-cost or free housing designated their location. They used the settlement process as a means for population dispersal. Most of the immigrants originating from North Africa and Asia were directed to the new development towns (many of which had begun as mabarot) and to moshavim (agricultural settlements). ${ }^{4}$ They were established by the State and located primarily on the national periphery of Israel (the Galilee in the north and the Negev in the south). The industries established in these towns were based on textiles and food, which do not demand skilled labor and pay relatively low salaries. Later this periphery became socioeconomic inferior. At the same time the large cities (Tel-Aviv, Haifa, Jerusalem), the smaller cities in the core of the State (Ramat-Gan, Netanya, Petach Tikva) and the moshavot extended significantly. The polarization between Israel's core and its periphery had grown.

\section{Period III: 1952-1966}

Following the early years of mass immigration right after statehood, the rate of Jewish immigration declined after 1951 and varied between low and moderate levels. During the period 1952-1966, 587,200 Jews immigrated to Israel and at the same time 155,000 thousand outmigrated - an addition of about 30 percent to the population of about 1.4 million at the beginning of the period. Consequently, the mean annual growth rate of the Jewish population decreased from about 23.7 percent (during 1948-1951) to 3.5 percent (during 1952-1966) (see table 2). This was still an impressive rate by international standards but small compared to

\footnotetext{
${ }^{4}$ The mabara was a new experimental type of settlement. It was a large extended camp, usually in proximity to cities or existing settlements. People were housed in tents or huts of wood and tin. Public services such as health, education, day-care centers, employment centers, etc. were provided by the government. By the end of 1952, 250,000 immigrants lived in 113 mabarot (Naor, 1986; Eban, 1972).
} 
the early years of the state. Most of the immigrants during this period came from the traditional countries of Eastern Europe (excluding the USSR) and from North Africa.

During the 15 years between 1952-1966 a cyclical behavior of immigration can be observed with similar cycles of ups and downs. During 1952-1954 immigration dropped very dramatically, net migration totaled 20,200 and immigration accounted for only 17 percent of the population growth. Moreover, 1953 was the only year since statehood (until today) when the net migration balance (immigration-emigration) was negative. During 1955-1957 immigration accounted for 58 percent of population growth, the share dropped to 32 percent during 1958-1960, increased again to about 59 percent in 1961-1964 and dropped again to 30 percent during 1965-1966. For the entire period of 15 years the migration balance was responsible for 46 percent of total Jewish population growth.

The non-Jewish (Arab) population grew almost exclusively as a result of natural growth, based on high fertility rates. The annual growth rate is around 4 percent and at the end of 1966 the non-Jewish population accounted for 12 percent of the total population. It is composed of 223,000 (8.4 percent) Moslems, 58,500 (2.2 percent) Christians, 31,000 (1.1 percent) Druze and others (Annual Statistical Abstracts, various issues; Rabi, 1968).

\section{Period IV: 1967-1988}

The Six Day War in June 1967 united the city of Jerusalem and reawakened the desire of Jews all over the world to immigrate to Israel.

After a sharp decrease in the number of immigrants during 1965-1966, when immigration dropped to about 15,000 annually, the trend changed again in the second half of 
1967..$^{5}$ In 1967 the number of immigrants rose to 18,056 and in the following year it was $24,107$.

The sources of this immigration wave were different from the previous two waves - more than half of the immigrants now came from Australia, Canada, Latin America, South Africa and the United States. ${ }^{6}$ Others came from Western Europe. There were still immigrants from Asia and North Africa, but now they were of a higher socio-economic status compared to their counterparts from those countries who left during 1948-1967 (Achiram, 1969, 1971, 1973). Many of these immigrants left family and property in their countries of origin and were willing to try life in Israel while retaining the option for return. This is indicated by the preference of the majority of them for the status of Temporary Resident or Tourist rather than full citizenship. ${ }^{7}$ A survey conducted by the Ministry of Absorption in 1970 reveals that 50 percent of the temporary residents who arrived in Israel between June 1969 and October 1970 returned; most of them were unmarried and the main problem they reported was housing. ${ }^{8}$

These changes imply that immigration is no longer exogenous to the social and economic climate of Israel, but rather becomes an endogenous factor. The size and composition of immigration depends on absorption opportunities which, in turn, are related to economic and social/political prospects. For example, unemployment or the high prices of housing depress immigration. High demand for specific occupations,(e.g., engineers in the late 1960s) encourages people in those fields to immigrate.

\footnotetext{
5 This shrink in immigration was one of the reasons for a two-year depression in 1966-1967 when growth ceased and the share of unemployed surged to about 10 percent of the labor force.

6 During each of the years 1969fr, 1970 and 1971 some 5,000 American Jews immigrated to Israel (Bein, 1982).

7 For example, in 1970, 64 percent of the immigrants from Western countries and 84 percent from North Africa refused citizenship and preferred a legal status of Temporary Resident. More indicators: 70 percent of potential immigrants (age 18+) visited Israel at least once before moving. Nevertheless, two months after arrival, onethird were not certain about the prospects of applying for full citizenship (Central Bureau of Statistics, Absorption Survey, 1970).

8 There was a shortage of houses and apartments (partly caused by the economic depression in 1966-1967) and prices rose significantly. Potential immigrants had difficulties in raising funds for high-standard housing.
} 
In the 1970s a new source of immigration opened up - the USSR. The three million Jews who lived in the USSR had been denied the right to immigrate to Israel. The Six Day War reawakened their national Jewish identity and their desire to come to Israel. In November 1969 an appeal was submitted to the UN committee for Human Rights, signed by 18 Jewish families from Georgia, Russia, declaring their desire to join their ancient nation in the State of Israel. It was an enthusiastic, heart touching appeal which received the support of the international community. Russia was torn between its policy of a closed society and close relations with the Arab countries on the one hand, and public opinion on the other hand, and reached a compromise; tens of thousands of Jews were given a permit to immigrate (Eban, 1972). As a result, about 150,000 Russian Jews immigrated to Israel.

The immigrants during this time period, most of whom had higher education, technological skills and capital, were less dependent on government aid and were able to decide for themselves the location of their homes. Approximately 70 percent of the immigrants of the 1970s chose the metropolitan areas of the country: Jerusalem, Tel-Aviv and Haifa; a minority settled in development towns and contributed to their intensified development (Lipshitz, 1991).

A totally different source of immigration which opened up in the mid-1980s (1984-1985) was Ethiopia. Confidential diplomatic efforts led to "Operation Moses" which brought 16,965 Ethiopian Jews to Israel. Although small in size, this operation has an emotional pioneering significance. These immigrants who came from a very different culture and society suffered cultural shock upon arrival and many of them are still dependent on public services and assistance.

During the 23 years between 1967-1989, over half a million Jews immigrated and 244,000 outmigrated, most of them former immigrants. As a result, the share of net 
migration in population growth was as low as 22.9 and the share of outmigration was about half of immigration. Population growth dropped to 2 percent annually.

At the end of 1989, the Jewish population totaled 3,717,100 and the Arab population 842,500. The annual rate of increase of the Arab population at around 3 percent (stemming from natural growth) resulted in a decrease in the share of the Jewish population to 81.5 percent, down from 88 at the beginning of the period (Annual Statistical Abstract, 1968).

\section{Period V: 1989-1998}

A dramatic change in the moderate inflow of immigrants started at the end of 1989. Triggered by Glasnost and as a response to worsening political and economic conditions in the former USSR, Israel witnessed a massive influx of Soviet immigrants. Between the beginning of 1990 and the end of 1998, the Israeli population of 4.56 million was supplemented by 879,486 immigrants - a growth rate of 19.3 percent. The Jewish population increased by 23.7 percent. The numbers were very high during the first two years: 199,516 in 1990 and 176,000 in 1991 and then slowed down to 70-80 thousand per year, during the years 1991-1998 (Israel, Labor Ministry, various issues). For the next coming years the estimates run around 50 thousand annually. While in the 1980s the annual growth rate of the Jewish population was between 1.4 and 1.8 percent, the 1990-1991 wave of immigration increased the Jewish population by 10 percent, in two years. The reduced immigration flow between 1992 and 1998 has contributed about 2 percent a year to population growth. Compared with immigration into the US and other receiving countries, this wave still stands out in its magnitude.

The inflow of Ethiopian Jews also continued in the 1990s. Between 1990-1993, 28,646 Ethiopian Jews arrived in Israel, 15,000 of them were airlifted in a single day in "Operation Solomon". They were later joined by smaller numbers of Ethiopians and recently by the 
Falasha Mura people. The Falasha Mura tribe advocates a Jewish origin which had to be denied at some stage due to religious persecution.

The absorption of the immigrants of the 1990s is marked by a new policy concept known in Israel as "direct absorption". This change began in the 1980s and is a reversal of the centralized policy which was applied in the first three decades of the State, when the government intervened directly and vigorously in all aspects of immigrant absorption.

Absorption is now directed by market forces and free choice of immigrants. Upon landing in Israel, immigrants now receive an "absorption basket" from the government, with a certain sum of money meant to last for a limited period of time. With this sum they may do as they see fit in all areas of life: housing, employment, education, consumption, etc. Direct absorption thus lets immigrants decide for themselves, based on their own personal considerations, how they wish to be absorbed. The declared goal of the government's directabsorption policy was to lessen the immigrants' dependence on national and local authorities, to streamline the absorption process itself and make it more flexible; and to speed up the immigrants' ability to begin functioning in housing, employment and social and cultural life.

While most of the Soviet immigrants took advantage of this new policy, this was not the case for Ethiopian immigrants. Being equipped with low levels of human capital and with skills which are not compatible with the requirements of the more modern Israeli economy and society, they are more dependent on government assistance. Many of them still reside in public absorption centers or caravan sites and did not integrate into the native labor market and society. This is true mainly for the older newcomers. The younger ones are better integrated into the educational system, the army and various vocational training programs which prepare them for the labor market. 
About 63 percent of the immigrants of the 1990s settled in the core districts (Tel-Aviv, Central and Haifa), 10 percent in the Jerusalem district, 24 percent in the national periphery: the Northern and Southern districts, and 2 percent in Judea and Samaria (Lipshitz, 1997).

At the end of 1996 the Israeli population totaled 5,759,400 Israelis, of which 80.5 percent are Jewish and 19.5 percent are Arab. The share of the Arab minority increased during the 1990s, despite massive Jewish immigration, due to high fertility rates.

\section{Immigration Streams: Education, Age and Profession}

The immigrants of the various waves originated from various educational, social and professional backgrounds. Each stream added another building block, as well as a finishing touch, to the Israeli society and economy.

The characteristics of the pre-state immigrations shaped the image of the Jewish community in Palestine. Many of the political leaders of the nascent State of Israel originated from these streams. The immigrants were young, well-educated and driven by a social Zionist ideology. Less than 16 percent of the immigrants (between 1929-1948) were older than 44 years and about half were 15-29 years old. As a result, over half the population in Palestine (between 1931-1947) belonged to the age interval of 15-44. Their youth and ideology facilitated a relative smooth adjustment to the different and difficult conditions in the host country.

The newcomers were highly educated. There is no systematic data of educational attainments, however there are many indicators: in 193193.4 percent of Jewish men aged 7+ and 78.7 percent of Jewish women (same age) were literate. There is evidence that this share did not drop until 1948 (Halevi and Kinov-Malul, 1968). Studying did not stop after arrival in Palestine. High schools, universities and cultural centers which were established during this time period enabled the population to flourish intellectually. Easterlin (1961), who did a 
comparative study of educational attainments of populations of various countries found that in the late 1940s Israel stood out significantly. For example, in 1948, almost 10 percent of the male Jewish population had a full academic education. This was higher than in the US and more than double compared to many countries for which he had data. Another striking feature of pre-state Israel's educational level is that, in contrast with the usual pattern, the average level of education was higher for the older age groups. An examination of figures of veteran population of 30 and over in 1954 (24 and over in 1948) shows that the percentage of higher education graduates for groups of 30-34, 45-59, and 60 and over were: 7.5, 11.4 and 10.9, respectively. While in most countries educational attainments drop significantly with increasing age, the opposite was true in Israel where the level of the two older age groups was noticeably higher than that for the youngest. This fact was relevant for the possibility of successfully assuming the wide variety of tasks involved in the establishment of a national state and the operation of a modern economy. Easterlin (1961) concludes, "It is no exaggeration to say that in 1948 the educational level of the Jewish population in Israel was close to the highest in the world" (p. 71).

Most of the immigrants had a profession when they entered the country: 15 percent of household heads among the newcomers (between 1919-1947) were trained for agricultural jobs, 36 percent for industry, 4 percent were clerks and 12 percent had academic and professional positions. Only 13 percent were unskilled workers (Halevi and Kinov-Malul, 1968). The relatively high proportion of agricultural professions was due to the special importance accorded to the return to agriculture in Zionist thinking; this was seen primarily as a means of changing the occupational structure of the Jewish community which hitherto had focused on commerce, finance and brokerage which were perceived as non-productive and even exploitative occupations. From 1882 until the outbreak of World War I, some 49 Jewish 
agricultural colonies were established in Palestine with about 13 percent of the Jewish population living in them (Eliav, 1978; Katz and Neuman, 1996).

The high socioeconomic status also led to improved health standards. Life expectancy rose in less than 20 years (between 1926 and 1944) by about 10 years, and reached the level of 64.1 years for men and 65.9 for women (Department of Statistics, Statistical Abstract of Palestine, 1944-45, p. 24).

While the pre-state immigrants laid the solid foundations for the Israeli society and economy, the various floors were built after statehood. The main floor was constructed between 1948-1951 when the Jewish population more than doubled in three years.

Immigrants of this time period had a lower socio-economic background than the veteran population and among them there were differences between the Easterners and Westerners. The former were less educated, more traditional, had larger families, less economic resources and lower skills (Rabi, 1968). These differences were responsible for the gap in employment and income between the various groups of immigrants. The reason for these differences was rooted in the cultural, social and economic natures of the countries of origin. The Asian and African countries were culturally and technologically underdeveloped and the Jews living there, like their native neighbors, were not equipped with modern education and skills. Upon arrival in Israel they had to adjust to the more modern society of the veteran population which originated from Europe and America (Achiram, 1973). Unfortunately the gap in education, standards of living and professions did not close.

Immigration during the third time period of 1952-1967 also originated from both Western and Eastern countries and socioeconomic differences between the ethnic groups persisted. According to the 1961 census, 69 percent of the Asian and African immigrants were literate, compared to 97 percent of the Americans and Europeans. Data for the academic year 1965/6 show that in the age group of 14-17, 60 percent of the native Israelis 
attended school, compared to 50 percent of immigrants from Europe and America (Westerners) and 30 percent of immigrants from Asia and Africa (Easterners). At the academic institutions, 60 percent belong to the first ethnic group, 30 percent to the second and only 10 percent to the third. Education gaps combined with other background differences led to gaps in their standard of living. Labor Force surveys and Income surveys conducted by the Central Bureau of Statistics in the 1950s and 1960s show that while housing and the standard of living improved constantly, the ethnic gap persisted, partly as a result of educational and professional differentials. For example, in 1965, 80 percent of Western families had living conditions of less than two persons per room, compared to only 35 percent of Eastern families. In 1963/4 the average income of an Eastern family was about 65 percent of that of a Western family. As Eastern families were larger than Western families (average family size of 4.8 and 3.1, respectively) meaning that the differences in income per person were even larger (Rabi, 1968).

The immigrants of the 1970s and 1980s were very different from those who came in the first two decades of statehood. They came from Western countries and from the USSR and the majority of them were equipped with high levels of human capital and trained in professional occupations.

\section{Insert table 4 here.}

Table 4 presents educational attainments of Soviet immigrants in comparison to the Israeli Jewish population. Over 50 percent of them had a post-secondary education compared to 20 percent of Israelis. About one-quarter had completed more than 16 years of schooling, compared to less than 10 percent of Israelis. Only 0.1 percent of the immigrants of this wave had no schooling at all, as opposed to 6.6 percent of Israelis.

Insert table 5 here. 
Table 5 gives the occupational distribution of the 1970-1979 immigration and the distribution of Israeli workers in 1977. The percentage of immigrants with academic and scientific professions is four times larger than the corresponding figure for Israeli workers (30 percent and 7.5 percent, respectively). About 15 percent are engineers and architects and 5 percent are physicians (Gur, Vinokur and Bar-Chaim, 1980). The percentage of service and agricultural workers is very low among the immigrants.

However, despite the high levels of human capital, the Soviet immigrants had major problems of adjustment to the Israeli labor market. The source of these problems was rooted in the Russian centralized economic system and its technological inferiority as compared to the West. Many of the newcomers needed some sort of training, retraining in a new profession, or down-grading.

\section{Insert table 6 here.}

The educational attainments and professional distribution of the recent mass immigration of Soviet Jews are similar to those of the previous wave. They, too, have an exceptionally high level of education and prior experience in academic jobs (table 6). Over 55 percent had post-secondary education, compared to about 25 percent for the native-born population. More than half of them held academic and managerial positions before immigration: 15 percent were engineers and architects, 7 percent were physicians, 18 percent were technicians and other professionals, and 8 percent were managers. ${ }^{9} \quad$ The Soviet immigration contributed to a significant increase in the educational attainments of the Israeli population. Data from the most recent census of 1995 , which were recently released, reveal that 70 percent of Israelis aged 25-64 have a high school diploma, 35 percent have post-secondary education,

\footnotetext{
${ }^{9}$ As an illustration, 57,400 of those who arrived until the end of 1993 defined themselves as engineers and 12,000 as physicians. These numbers should be compared with 30,200 engineers and 15,000 physicians in Israel, in 1989.
} 
and 20 percent have an academic certificate - up from 11 percent from the previous census. This dramatic increase is largely due to the immigration from the former USSR. In an international comparison of university graduates Israel ranks third, after the United States with 25 percent academics and the Netherlands with 22 percent. $^{10}$

In contrast to the high quality of education and skills of the Soviet immigrants, the rather small Ethiopian group embodies low levels of human capital.

There is little systematic data on educational and professional attainments of the Ethiopians. The Brookdale Institute carried out a few surveys among Ethiopians who arrived during "Operation Moses" in the mid-1990s and we can assume that the results would not be very different for the Ethiopian immigrants of the 1990s. A representative survey conducted among 1,200 immigrants, aged 16-30, reveals that over one-third (53 percent of women and 23 percent of men) lacked any formal education on arrival in Israel. Only few were able to join Israeli high schools upon arrival and the great majority joined vocational and training courses funded by the Ministry of Labor, the Jewish Agency and the Joint. Eighty-five percent of young male immigrants and 39 percent of female immigrants were enrolled in vocational courses and another half took shorter courses of one year or less. The syllabi were planned to meet the special needs of these immigrants; to provide them with general education and Hebrew language knowledge, and at the same time give them a technicalvocational education to help them integrate in the labor market. Indeed, many of the course completers were later occupied in skilled professions and jobs. About one-third were employed as skilled workers in industry and construction, 13 percent were technicians and another 13 percent worked in skilled service jobs. Only one-third remained unskilled

\footnotetext{
${ }^{10}$ In all other European countries the percentage of academics is significantly lower, e.g., Poland and Ireland, 10 percent; Switzerland, 9 percent; Italy and Turkey, 8 percent; Austria, 6 percent (OCED Statistics, Ha'aretz, June 1, 1998).
} 
workers. The results are impressive given that in Ethiopia the great majority lived in rural areas and worked as agricultural laborers. They therefore had to undergo a complete occupational transformation (Lipshitz and Noam, 1993).

A comparison of the age distribution of Soviet versus Ethiopian newcomers shows that Ethiopian immigrants are much younger than immigrants from the former USSR. Over 30 percent of the former are under the age of 10 and over 60 percent are under 20 . Only 5 percent are older than 65. Respective percentages for the Soviet immigrants are: 14 percent aged 0-9, 29 percent at the age of 0-19 and 13 percent aged 65+. The major differences in the age distributions are due to the much larger families among Ethiopians and the higher life expectancy among Soviets. There is increasing sensitivity to the special problems of Ethiopian youth in coping both with the developmental process undergone by every adolescent, and with the special problems arising from immigration and the need to adjust to a new society. These problems are especially serious, given that most of the families arrived in Israel with very limited educational and financial resources, and that many live in peripheral towns, which are often characterized by limited resources and a shortage of services. Service personal cited a variety of problems among Ethiopian immigrant youth: problematic parent-youth relationships; academic difficulties; difficulties in parental communication with school staff; behavioral and identify problems; and severe economic difficulties. Recently, a number of changes have been made in the policies of the government and of public agencies concerning Ethiopian youth. Maximum effort is being invested in three directions: integrating youth into schools in their home communities; referring youth studying outside their home communities to high-level boarding schools and to matriculation programs; and tracking down and treating youth at risk (Lifshitz, Noam and Segal, 1997).

It is worth noting that this overall trend of an increase in educational attainments of immigrants (since the 1970s) which is observed in Israel is not a worldwide phenomenon. In 
the US the relative educational levels of successive immigrant waves fell dramatically in recent decades; in 1970 the typical immigrants who had just arrived in the United States had 11.1 years of schooling, as compared to 11.5 for the typical native workers. By 1990, the typical immigrant had, upon arrival, 11.9 years of schooling, as compared to 13.2 for natives. This also led to a corresponding decline in the relative wage of immigrants (Borjas, 1994b). This trend of decrease in skills exists even in Canada, even though it encourages immigration of the highly skilled, and is screening about one half of an immigrant cohort for human capital characteristics. Although immigrants still tend to be more concentrated in the higher skilled sectors than is the case with the native born, and less concentrated in more traditional sectors, the overrepresentation on the skilled occupations appears to decline across subsequent entry cohorts (Green, 1995).

\section{Immigrants' Assimilation and Effects of Immigration on the Local Economy}

Many studies in the economics of migration explore the issue of how well immigrants have assimilated into the labor market of the receiving country, and what impact they have on economic growth and on employment opportunities for natives (Borjas, 1994a). The answers to these questions have clear policy implications, e.g., if the local population benefits from immigration, it may be cost-effective to subsidize it. The discussion of these questions has been debated heatedly in many countries and since the 1970s there has been a growing number of studies on these issues. The introduction and development of computers and computational methods facilitated such studies. Simultaneously, statistical methods have been improved and new procedures (e.g., for the use of panel data) have been proposed. This contributed to a sophisticated econometric analysis of the data, compared to the descriptive nature of data analysis used before. 
The Israeli case is used in many of these studies, as Israel provides a large, rich and varied pool of immigrants to observe. They come from a wide range of countries and have vast educational and occupational backgrounds. The lesser degree of self-selection among immigrants to Israel also makes the Israeli experience well suited for such research. The availability of rich data bases such as the 1972 and 1983 censuses, many absorption surveys, and panel data of the last two waves of immigration from the Soviet countries, facilitates such studies.

Three questions will be addressed: 1) How well do immigrants perform in the Israeli labor market? 2) What are the effects of immigration on employment opportunities and the welfare of the native population? and 3) What is the relationship and causality between immigration and growth rates of the local economy?

\section{Immigrants Assimilation in the Local Labor Market}

When immigrants first arrive in a new country, they are at a disadvantage in the labor market, relative to natives with comparable demographic characteristics and skills. Typically, they start with lower wages and subsequently experience a relatively fast earning growth (Borjas, 1994a; LaLonde and Topel, 1991). This rise in earnings is a result of several factors: immigrants learn the local language and become familiar with local institutions and labor market conditions, they accumulate country-specific human capital and experience, and they find a better match for their occupational skills and move up the occupational ladder. As time since migration passes, this earning differential diminishes. Chiswick (1978) in a pioneering study, found that in the US in the 1970s, earning parity was reached about fourteen years after arrival, and thereafter immigrants earned more than natives.

In Israel this question has been studied mainly for the immigrants of the 1970s and of the last influx of the late 1980s and 1990s. Friedberg (1995) used the 1983 census to study 
wage-convergence of some 54,000 male, full-time, salaried immigrants, aged 24-65, from all immigration cohorts. She found that upon arrival in Israel, the average immigrant earns about one-third less than a native-born Israeli with similar characteristics. This earning gap diminishes over time, but is eliminated only after 35 years. The assimilation rate of immigrants in Israel is therefore approximately 1 percent per year. ${ }^{11}$

The innovation of her paper is to introduce to the analysis a distinction between human capital that was acquired abroad and that which was acquired domestically. Her study demonstrates that the most important factor determining the gap in the standard humancapital-corrected earnings of immigrants and natives is the source of their human capital. Foreign human capital earns a lower return than domestic, and this fact alone is sufficient to explain the residual earnings disadvantage of immigrants. Friedberg also found a difference in returns to education by country of immigrant origin - the return to education obtained abroad is higher for immigrants from Europe and the western hemisphere than for immigrants from Asia and Africa. These patterns may reflect differences in educational quality across continents of origin, as well as compatibility of the education obtained abroad with the requirements of the host labor market.

Beenstock (1993) and Chiswick (1997) investigated the interdependence between employment absorption and Hebrew proficiency. Beenstock used panel data on immigrants who came to Israel in the 1970s. These immigrants were interviewed on arrival, after one year in Israel and after three years. The data are unique because they refer to different functions of language (understanding, speaking, reading) and record ability at different time points. Examination of panel data for 6,700 immigrants who arrived in Israel during the 1970s reveals that Hebrew proficiency tends to promote employment absorption. It enhances

\footnotetext{
${ }^{11}$ There is no consensus in the literature regarding assimilation rates in the United States. Most estimates fall in the range of 0-2 percent (Borjas, 1985, 1990; Chiswick, 1978; LaLonde and Topel, 1991).
} 
participation, reduces unemployment and promotes occupational convergence. ${ }^{12} \mathrm{He}$ also found that while Easterners were faster than Westerners at language absorption, the opposite was true for employment absorption. This was evident for participation, employment and occupational convergence.

Chiswick used the 1983 census data to analyze the effects of Hebrew fluency on labor market earnings of male immigrants. By using census data he was able to refer to 56,000 male immigrants coming from a wide range of countries of origin with various lengths of duration in Israel. His analysis reveals that earnings increased monotonically with the ability to speak Hebrew. The patterns are very similar to relationships in English speaking immigrant receiving countries (Chiswick, 1991b; Chiswick and Miller, 1992, 1994, 1995).

Ofer, Vinokur and Bar-Chaim (1980) studied the absorption process of Soviet immigrants who arrived in Israel between 1974-1976. They used panel data and absorption surveys and their results draw a picture of very successful economic integration. Immigrants' standard of living is higher compared to their standard of living in Russia, and in some cases even in comparison with the native population. Immigrants reported an increase in most personal consumption components, with the exception of culture only. The absorption of young immigrants was more successful than that of older ones and a positive correlation was observed between assimilation and education, professional status and gender (women were more easily integrated than men). However, occupational convergence took time and, at least during the first few years in Israel, immigrants form the Soviet Union "traded downward", i.e., doctors became nurses, nurses became auxiliary help, etc. Similar results have recently been obtained by Amir (1993) for immigrants with higher education who belong to the same immigration stream.

12 Wage data were not available and therefore wage-convergence could not be estimated. 
Parallel to the Soviet Jewish immigration to Israel in the 1970s and the early 1980s, about a quarter of a million Soviet Jews migrated to the United States at the same time. ${ }^{13}$ Chiswick's (1990, 1991a) comprehensive study of their economic integration into the US labor market facilitates a comparison between assimilation of similar groups of immigrants into two different labor markets. Chiswick's studies suggest that immigrants to the US faced greater problems than those met by their counterparts who migrated to Israel. According to the US census of 1980, Soviet immigrants were also less successful compared to other immigrant groups; their average income was 30 percent lower than that of other immigrants and about 60 percent lower than the income of immigrants from Europe. Only half of the migrants who had academic, technical or managerial professions were employed in their original job, and a substantial share of them were unemployed. One of the major reasons for the disadvantaged situation of the Soviet Jewish immigrants to the US was their poor command of the English language. In Israel immigrants acquire the language (Hebrew) faster and more easily due to public language schools (ulpan) which they may attend at no charge for six months.

Eckstein and Weiss (1997) have analyzed occupational convergence and wage growth of the recent large wave of high-skilled immigrants from the former Soviet Union. Using panel data and their findings suggest that upon arrival immigrants receive no significant return on imported human capital (either schooling or experience); with more time spent in Israel, these returns increase but a gap between returns obtained by immigrants and those obtained by natives remains. This is reflected in returns of 0.03 to schooling acquired abroad, compared to returns of 0.07 that native Israelis receive. Immigrants eventually obtain the same return

13 The US was one of the major countries of destination for Jews who migrated out of their countries of origin. Until the 1920s it hosted the majority of Jewish migrants. Since the 1930s and, significantly after 1948, Israel took the lead. All together, about 7 million Jews changed countries of residence in the last millennium (Della Pergola, 1991). 
on experience as natives but convergence is slow. Occupational convergence is also slow, after 15 years in Israel, the occupational distribution of immigrants tends to converge to that of Israeli workers but, in the short run, a significant downgrading is observed.

Immigrants start with low wages and experience rapid increases; in the initial five years following arrival, wages of immigrants grew at a fast rate of 6.4 percent a year. Half of this growth can be ascribed to rising rates of return to skills. Occupational transitions account for growth of 3 percent per year (among immigrants with 16+ years of schooling) and accumulated experience in the local labor market accounts for about 1.6 percent per year. As an illustration, an immigrant who arrived at the age of 30 with $16+$ years of schooling initially earns, on average, only half the wage of a comparable native Israeli. By the age of 50 , the wage of this same immigrant will be 10-16 percent lower than that of a comparable native worker.

A series of studies referred to wage differentials between immigrants from various continents and, in particular, between Easterners and Westerners. Following the mass immigration to the nascent state of Israel at the end of the 1940s and the beginning of the 1950s, large wage differentials between the two ethnic groups were observed. Subsequently these gaps narrowed. As Amir $(1980,1987)$ has shown, in 1957-1958 a gap of 37 percent was observed between earnings of heads of families who originated from Asia and Africa (Easterners) and those from Europe and America (Westerners). By 1963-1964 the gap fell to 32 percent. In 1968-1969 the weekly income difference for family heads was 26 percent, and in 1975-1976 it dropped to 13 percent. The wage difference between all employee immigrants (and not only heads of families) was larger; about 35 percent in 1969, 17 percent in 1976 and 16 percent in 1982. The social and economic significance of these wage gaps can be related to the factors determining them. The respective roles of human capital differences and discrimination have also been examined. It was found, for example, that the mild 
decrease in the wage gap between 1957-1958 and 1963-1964 was comprised of similar decreases in each of the two components. With regard to the highly significant decrease between the end of the 1960s and the middle of the 1970s, two opposite conclusions were drawn; according to Weiss, Fishelson and Mark (1979) the decrease is attributable largely to a decrease in the explained portion of human capital differences while Amir (1980) claims that the share of the unexplained component of discrimination is larger.

The more recent immigration waves (since the 1970s and up to the present date) are composed of Westerners (the great majority from the Soviet countries) with a negligible proportion of Easterners originating from Ethiopia. A distinction between assimilation of Westerners versus that of Easterners is no longer relevant. However, wage and occupational differentials still exist, stemming partly from differences in educational attainments and other socioeconomic background variables. These gaps result in social and political tension. ${ }^{14}$

\section{The Impact of Immigration on the Native Labor Market}

A rapidly growing literature documents the impact of immigrants on the native labor market of the receiving country. A pioneering empirical paper on this issue was written in 1970 by Jones and Smith who explored the impact of immigration from the British Commonwealth to Britain, and found that it neither increased unemployment of natives nor overused state welfare funds. Most of the studies which were conducted thereafter investigated the following issues: Do immigrants have an adverse impact on native earnings and employment opportunities? If so, how large is the loss in the economic welfare of the natives? Borjas (1994a) reports studies done in the US, Germany and France in which correlations between native wages and the immigrant share in local labor markets are

14 For more information on ethnic, economic and social stratification see Cohen, Bechar and Raijman (1994); Neuman and Silber (1996); and Neuman and Oaxaca (1997). 
estimated. All these studies do not support the hypothesis that employment opportunities of native workers are adversely affected by immigrants. Zimmermann (1995) points to similar results for Europe. However, Borjas' appraisal of the literature suggests that "we still do not fully understand how immigrants affect the employment opportunities of natives in local labor markets, nor do we understand the dynamic process through which natives respond to these supply shocks and reestablish labor market equilibrium" (Borjas, 1994a, p. 1700).

In Israel, this question has been addressed by Simon (1976) who examined the Soviet immigration wave of the 1970s and by Hercowitz and Yashiv (1997) who looked at the last massive inflow of the 1990s.

Simon (1976) explored the effect of the Soviet immigration of the 1970s on the income of native Israelis. Whereas most studies of this kind looked at correlations and elasticities between wages and the share of immigrants, Simon employed a different estimation technique which considered the following elements: 1) The significant burden which immigrants impose on the State welfare system; Israel provides new immigrants, for a period of three years, with various services of housing, health, education, income maintenance and social services. Subsidies for housing are particularly high; 50 percent of the rent for the first three years and, in the case of purchase of an apartment, the immigrant receives inexpensive loans, 2) The increase in the size of the labor force results in a decrease in the capital/labor ratio and might also lead to economies of scale and 3) Immigrants who serve in the army and spend several years in mandatory service contribute to defense production. This is a very significant contribution in a state like Israel which, in the 1970 s, devoted to defense 25 percent of its national income. After netting out the first two negative effects by the third very positive one, Simon came up with the following estimates: the net effect is negative only for the first year after migration (-10.75 percent), close to zero (-0.8 percent) for the second year and then increases gradually up to 26 percent seven years after migration and, as much as 
59 percent 50 years later. Three years after migration the immigrant pays back his absorption costs and from then on he contributes to the welfare of the State. Returns to investment in absorption therefore are very high, according to Simon's calculations.

As for employment opportunities, in the 1970s the Israeli economy enjoyed full employment. Unemployment rates were around 3-4 percent for both natives and immigrants and immigration had no significant effect on unemployment. In the 1990s unemployment rose to 5-7 percent and the last massive wave of immigration arrived into an economy with above normal unemployment rates. In this case the effect of mass immigration on employment rates is of special interest. Hercowitz and Yashiv (1997) proposed a theoretical model dealing with several aspects of this process and have tested it empirically. The model emphasizes the point that immigrants are absorbed into the local labor market gradually and therefore the effect on the employment opportunities of the native labor force occurs with a lag. It also incorporates the phenomenon whereby the immigrants first "tradedown" their skills and only later they climb the occupational ladder. The model caters for substitution and complementarity among the various skill groups and takes into account effects from the markets for goods. The two main findings are: 1) The effect of the immigration wave of the 1990s on natives' employment is for the most part positive. This is explained by aggregate demand effects. This finding is stronger than those of many other papers which found insignificant or very small negative effects (e.g., Card, 1990; Borjas, 1994b; Zimmermann, 1995) and 2) The effect of immigration differs for different native occupational groups. This is explained by the occupational convergence of these highly skilled immigrants - they first enter low-skill occupations and gradually work their way up. 


\section{The Entwined Growth of Population and Product}

The third issue we examine are the growth rates of the Jewish and then the Israeli economy during one hundred years of immigration.

Under the British mandate a Jewish economy existed alongside an Arab one. The Jewish population at the beginning of the century was so small that it hardly constituted an economic entity. The rapid growth of that population during 1919-1948 (487,000 immigrants, see table 1) with its own institutional structure, accompanied by a concurrent huge growth of product, created a distinct Jewish economy, separate but not completely isolated from the Arab sector (Metzer, 1982). Since 1948, the Jewish economy and the economy of Israel have been synonymous, with only a small Arab sector integrated into the general economy. ${ }^{15}$

A full analysis of the performance of the Israeli economy and its interrelations with population growth is beyond the scope of our review. ${ }^{16}$ We will concentrate on population as an engine of growth of product. As the estimates of product for the years 1882-1948 and the estimates for the first years of statehood are very rough, our discussion will not refer to these time periods and we will use 1950 as our starting point.

\section{Insert table 7 here.}

Table 7 documents annual population and product growth rates (total product, per-capita product and per-capita consumption) for the period 1950 and up to the present date. The record of long-term growth in both product and in Jewish population is truly exceptional by world standards. It is at a record high for the first years of statehood. In 1951 GDP increased by 30.1 percent and per-capital GDP surged by 10.3 percent. A significant share of GDP was

\footnotetext{
15 After the 1967 war, the West Bank and the Gaza strip became part of the Israeli market and the labor pool there both benefited from the higher wages in the Israeli market and served as a buffer to domestic fluctuations (Ben Portath, 1986).

16 For a more detailed analysis see Bein (1976) for the pre-State period; Gaathon (1964a, 1964b, 1971), Prop 1968) and Halevi and Klinov-Malul (1968) for the period 1948-1966; Ben-Porath (1986) for 1922-1982, and Hercowitz and Meridor (1991) for 1989-1991.
} 
government consumption, however per-capita private consumption also rose by 3.8 percent.

During the period 1952-1966 the figures dropped to $10.3,6.2$ and 5.3 respectively. These

figures are still very high by any international comparison.

Richard Easterlin (1961) was so impressed by the Israeli experience that he wrote in 1961:

Fortunately, despite the usual difficulties of statistical collection and organization in a newly founded state, reasonably acceptable estimates of real national product are available back to 1950. For the eight years since this date, these tell a story of remarkable accomplishment - a growth in total gross national product of around 140 per cent, an annual rate exceeding 11 per cent. While data for all nations are not available for comparison, it seems certain that no other nation attained a comparable rate during this period. Of course, one may point to the extraordinary addition to the nation's labor force, one of the major inputs into an economic system, as creating some presumption that total product would rise significantly. But, when one turns to the figures for growth of real per capita product, the result is still amazing - an increase of 50 per cent during the period, an annual rate of over 5 per cent. Though not the highest in the world during these years, such a rate would put Israel well up among the leaders and would be warmly welcomed by any nation seeking economic development. Moreover, few nations, if any, were confronted with equally adverse circumstances. For, if one harks back to classical stationary state reasoning, such growth in population in an economy of poor and limited resources would be expected, other things remaining unchanged, to lead not to a rising or even a stationary per capita product, but to a declining one. (p. 64.)

An international comparison presented by Kuznets (1973) adds more perspective to the

Israeli figures.

\section{Insert table 8 here.}

Table 8 shows growth rates for various countries, for the period $1950-1968 .{ }^{17}$ Only Japan precedes Israel with an annual GDP growth rate of 9.7 (compared to 9.2 in Israel). Taiwan comes close with a rate of 8.5. When per-capita growth rates are compared, Japan stands out again (with a rate of 8.6) while Israel is close to seven other countries: Austria, Germany, Greece, Italy, Puerto-Rico and Spain, with growth rates of around 5 percent.

17 Communist countries are excluded due to their different eocnomic/political system. 
Kuznets concludes that in 1965 , out of 106 non-Communist economies with a population of one million or more, only very few reached growth rates higher than Israel.

Kuznets (1972) also raises the question of causality between the influx of immigrants during the late 1940s and early 1950s and the very impressive growth rates during 1951-1966. He does not give a clear-cut answer as there are counter observations. There are countries with similar demographic backgrounds and low productivity rates and also countries with similar demographic experience and yet low growth rates. He felt that ideological and moral factors contributed to the phenomenal economic success; the strong belief that the Jewish state has to be rebuilt, the sense of unity both in the country and among world Jewry; and the existence of a hostile and isolated environment.

1966-1967 were years of recession when per capita GDP and per capita consumption dropped by about 1 percent. One of the traumatic lessons of this recession was the ensuing wave of emigration), which indicates that emigration responds to economic fluctuations. In 1968 the economy was back on track and between 1968-1972 GDP rose by 11.9 percent annually while the population increased by 2.9 percent. As a result per capita GDP grew more than 8 percent each year. The two decades of the 1950s and the 1960s were therefore years of rapid economic growth in which gross domestic product rose about 10 percent annually. There were relatively few changes in the average annual growth rate of the population (around 3.5 percent) and, as a result, product per capita increased by more than 5 percent annually. By the late 1960s only several other countries (Hong-Kong, Korea, Singapore, Taiwan and a few oil exporters) performed as well as Israel or better.

In the third decade a sharp downward trend set in. Between 1973-1980 the population grew at an annual rate of 2.2 percent, GDP at 3.1 percent and GDP per capita at 1 percent only. After 1973, in addition to a slowdown in immigration, Israel underwent external shocks; the energy crises of 1973-1974 and 1979 with associated changes, made the 1970s a 
period of world-wide slow growth. Rising defense expenditures after the 1973 war and the return of the Sinai oil fields to Egypt as part of the Camp David Accord exacerbated the problem.

This trend of slowdown of immigration and growth continued in the 1980s as well. Between 1981-1989 the Jewish population grew by less than 1.5 percent annually, GDP rose by a yearly average of 2.7 percent and per capita GDP by 1.1 percent. This trend has changed altogether with the mass immigration of Jews from the former Soviet Union which started toward the end of 1989. This wave, which stands out in its magnitude, reached population growth rate peaks of 6.2 and 5.0 percent in 1990 and 1991, respectively, and then slowed down to an annual population growth rate of 2.4 during each of the years 1993-1998. The increase in population was accompanied by annual GDP growth rates of over 5 percent during 1990-1995. ${ }^{18}$ Per capita GDP growth rates were less consistent and ranged between 0.1 percent in 1991 and over 4 percent in 1994 and 1995. The high growth rates of 1994-1995 are probably a result of the assimilation process and the increase in the productivity of the immigrants who arrived in 1990-1991. The rate of growth of the Israeli economy, during the first half of the 1990s, has been one of the highest in the world, more than double the rate of the OECD countries, the G-7, Japan, the United States or the United Kingdom. ${ }^{19}$ Only some newly industrialized Asian countries (Singapore, Korea) preceded the Israeli economy (International Monetary Fund, 1997, table A2, p. 148). Starting in 1996, the trend of high growth rates has changed dramatically. In 1996 GDP growth rates decreased to 4.7 percent (from 7.1 in 1995) and per-capita GDP growth rate dropped to 2.5. During 1997-1998 economic activity continued to decrease and the economy witnessed a recession. Annual

\footnotetext{
${ }^{18}$ The Israeli GDP growth rate figures (in percent) are: 1990 - 6.1, 1991 - 6.3, 1992 - 6.6, $1993-3.5,1994-6.8$, 1995 - 7.1, (table 7).

${ }^{19}$ The G-7 includes Canada, France, Germany, Italy, the United Kingdom and the U.S.
} 
GDP growth rates plunges to 2.7 in 1997 and only 2 percent in 1998 and per-capital GDP grew by 0.1 percent in 1997 and -0.4 percent(!) in 1998. Per-capita personal consumption also decreased significantly (table 7). The recession was the result of several economic factors: the economic crisis in the Far East and in the former USSR; security instability in the Middle East; a significant drop in the number of new immigrants.

\section{What Have We Learned, What Should be Done?}

\section{Failure to Absorb - Return Migration of Immigrants to and from Israel}

Immigration decisions are reversible and part of the immigrants into Israel out-migrated, either to their country of origin or to a third country.

Emigration from Israel is frequently stigmatized as unpatriotic. It evokes negative sentiments and even hostility on the part of government officials and the general public. While immigrants who come to Israeli are described as olim ("going up"), those leaving the country are labeled yordim ("going down"). The attitude is more tolerant toward recent immigrants who are migrating back than towards native Israelis who emigrate. Yet, with a growing number of Israelis residing abroad, the social stigma of being a yored has significantly weakened. In any case, return-migration indicates failure to absorb and the identification of the factors leading to the phenomenon might lead to an improvement of absorption policies.

Table 2 includes figures of net migration and immigration. Calculation of emigration out of immigration reveals that the shares have changed over time: from right after statehood, to 23 percent during 1952-166, up to 44 percent at the period of 1967-1989 and down again to 20 percent during 1990-1996. However, these figures include emigration of Israeli natives and return-migration of newcomers as well and it is not possible to distinguish between the two different outflows. Nonetheless, the motives for return-migration can still be explored 
using panel data described below, which follow immigrants up to five years after immigration to Israel.

The study of "return-migration" has been relatively neglected in the economic literature. Yet the little evidence which is available suggests that the process is far from marginal. Jasso and Rosenzweig (1982) report that possibly as many as 50 percent of legal immigrants to the US outmigrated within eight years after arrival. In prestate Israel, of the 13,000 Jews who arrived in Palestine in 1926, more than half left; in 1927, emigration, for the first time, exceeded immigration (Elizur, 1980). This was also the case in 1966. Beenstock (1993) reports that among the immigrants of the late 1970s, the return migration rate among young single immigrants from North America reached 40 percent within more than three years.

The literature offers three alternative hypotheses for return-migration: 1) Ramos (1992) presents a "self-selection model" and claims that unskilled workers remain while the more skilled and educated workers migrate back to their country of origin and take advantage of the higher returns to skills in the native country. A sample of return-migrants to Puerto-Rico supports his hypothesis. 2) Tunali (1986) argues that re-migration is an option that will be planned in advance if it enhances life-time earnings. He uses data on internal re-migration in Turkey and offers a very loose test for his theory. 3) The "unfulfilled expectations hypothesis" suggests that the return migrant goes home because life in the host country did not turn out to be as good as expected (Beenstock, 1993). This is probably a major reason in the Israeli case where many of the newcomers are ideological immigrants who may suffer from "burn out" and a culture shock which drives them back home. Return-migration is also motivated by economic factors (such as unemployment or housing problems), although they played only a secondary role in the decision to immigrate to Israel. Moreover, most Westerners take a cut in living standards on arrival in Israel and economic considerations play a major role in the decision not to immigrate to Israel. This is the case for Western Jewry as 
well as for North African and Iranian Jews who preferred to go to France and North America. For similar reasons there has been a high drop-out rate among Soviet Jews who received Israeli exit visas but opted for North American while ostensibly en route for Israel.

Until 1988 the American immigration policy was quite liberal and a large share of Soviet Jews preferred immigration to the US. The second hypothesis of life-cycle planning might apply to Soviet immigrants in the 1990s. Part of them chose Israel as a first stop with the plan of later migrating to North America.

There has been almost no empirical testing of the various hypotheses regarding returnmigration due to lack of data - return migrants cannot normally be observed once they have left. Israel and Germany are two exceptions, in that data exist on immigrants who left. In Germany the German SociaEconomic panel (GSOEP) contains such data, ${ }^{20}$ and in Israel the Immigrant Absorption Surveys follows immigrants during various stages after arrival and makes it possible to determine whether return migration has occurred. Such surveys have been conducted in the 1970s-1980s tracing the previous wave of immigration from the Soviet Union, and recently in the 1990s, following the last massive wave of Soviet immigrants. However, as this wave is still arriving the panel data collected so far is premature for the analysis of back-migration.

Two empirical studies by Blejer and Goldberg (1980) and by Beenstock (1993) investigated return migration of immigrants who arrived in Israel in the 1970s and the 1980s. Both used panel data from the Immigrant Absorption Survey (IAS) conducted by the Israeli Central Bureau of Statistics. This survey offers a rare look into the behavior of immigrants who subsequently re-migrated. The sampled immigrant households were interviewed three times; first two months after arrival when basic data on the immigrant and his family (both in

\footnotetext{
${ }^{20}$ See, for example, Licht and Steiner (1993) and Steiner and Velling (1992).
} 
the country of origin and in Israel) were collected. A second interview took place after a year when immigrants were questioned about their progress with language, employment, housing and social integration. If an immigrant could not be located at this stage, Border Control Files were checked to see if he left the country. If he had, relations, neighbors and friends were consulted to determine whether the departure from Israel was permanent or temporary. A similar interview was carried out three years after arrival. Here too, every effort was made to determine whether return migration occurred.

The IAS therefore offers a wealth of micro data on return migrants and enables an examination of whether experience in the first year had any effect on emigration decisions.

Blejer and Goldberg, using a subsample of the IAS, investigated return migration of Western immigrants to Israel (between 1969-1972) who migrated back within three years after arrival. They found that return migration was positively affected by economic factors of unemployment and housing density, but negatively affected by knowledge of Hebrew upon arrival, age and family size. The economic hardships contributed to the frustration of unfulfilled expectations. The age effect can be interpreted in terms of the life cycle model which suggests that older people have less to gain by reversing their initial decision to immigrate because they have a shorter time horizon. Family size raises the cost of returnmigration and knowledge of Hebrew upon arrival facilitates a softer and smoother integration process.

Beenstock (1993) used a subsample which covers a longer period, as well as nonWestern immigrants. He made a distinction between immigrants who left the country within the first year and those who left during the second and third years and also between the holders of various visa types (A-1 versus full citizenship).

Beenstock's findings suggest that Soviet immigrants are less likely to emigrate while the opposite is true for immigrants from Western Europe and North America. Immigrants on full 
visas are less likely to re-emigrate compared to A-1 visa holders. Visa status may reflect intentions at the stage of immigration; absorption experience with language and housing appears to be relevant in predicting the propensity of re-migration while unemployment does not seem to affect it.

Overall, the research lends support to an "unfulfilled expectations model", immigrants leave because they are dissatisfied with what they have experienced in their new country. Immigrants are more likely to remain if things go well for them.

These findings carry policy implications, some of which have already been recognized leading to changes in the absorption process of the immigrants of the 1990s. The government offered a limited amount of cheap housing and solutions but at the same time gave immigrants subsidies which enabled them to rent or buy apartments wherever they wish. Immigrants were offered training in many areas and employers who showed interest in employing immigrants were subsidized to encourage them to hire newcomers. Language schools (ulpan) took care of Hebrew acquisition. A future analysis of the IAS survey currently conducted will help us check of these steps contributed to the relatively smooth integration of this recent massive immigration flow.

Studies of emigration of native born Israelis (Lamdani, 1989) suggest that in this case emigration from Israel is motivated by economic factors such as unemployment and living standards. However, results of two samples of Israelis residing in the US (interviewed in 1972 and in 1977) presented by Elizur (1980), reveal that factors relating to personal development have the most significant effect on emigration. These include opportunities for higher education, professional training and the utilization of talent, as well as the desire to experience life in other countries. Thus the motives of Israelis coming to the United States are more of a pull than a push nature. Being aware of that and of the fact that migration caused by pull forces has greater chances for return (Lee, 1966), the Israeli authorities have 
recently changed their approach towards Israelis residing abroad. Israel has realized that they constitute a potential pool of immigrants and has employed various means to encourage them to return. Assistance in finding employing and housing, customs reductions, and loans for travel expenses are among the benefits to which returning Israelis are entitled. Elizur's (1980) study suggests that Israelis residing abroad should be encouraged to maintain their Israeli and Jewish identities (read Israeli newspapers, listen to Hebrew language broadcasts and send their children to Jewish schools). While this can not guarantee that Israeli immigrants will feel the need to return to Israel, it may considerably increase the chances. The estimates of native Israelis residing abroad are around 300,000 and they constitute a significant pool of potential immigrants. Other countries facing out-migration of natives might benefit from a similar strategy.

\section{Comparison of Absorption Policies of the 1950s and 1990s}

The absorption models used in the 1950s and 1990s are conceptually different. In the first three decades after statehood and especially in the 1950s, the Israeli government employed a highly centralistic model and intervened directly and vigorously in all aspects of immigrant absorption. This policy gradually changed in the 1970s and 1980s and the absorption of the immigrants form the former Soviet Union and Ethiopia in the past seven years has been marked by a completely new policy concept, known in Israel as "direct absorption". This policy constitutes a reversal in the manner of thinking regarding immigrant absorption; the newcomers are now given a sum of money and are free to choose how to allocate it, where to live, where and in which occupation to be employed, etc. Preferences and market forces are therefore responsible for the outcomes. Although, so far we have only a short perspective of this new policy, we can still draw some comparison and lessons. 
The absorption process of the 1950s is considered as one of the largest in human history in terms of the ratio of immigrants to the native population. During a short time period of three to four years, each of the Israeli natives absorbed more than one immigrant. This was done in a nascent state with very limited resources, engaged in the War of Independence with neighboring Arab countries. The absorption policy was centralistic; the state provided the newcomers with low-cost housing, employment, health and educational services. At the same time other national goals were set as well: 1) Population distribution: The state designated the location of immigrants which was motivated by political, economic and defense needs. Most of the immigrants were directed to development towns that had been established by the State and which were primarily located on the national periphery of Israel. 2) The development of an agricultural sector and basic industry. Given the centrality of agriculture in Zionist thinking, the Israeli government set an economic ideological goal of developing a strong agricultural sector and increasing the number of agricultural workers. Many of the newcomers were directed to agricultural settlements (moshavim) where the families owned their farms and cultivated them on an individual basis. At the same time, labor intensive industries have been established by the government in development towns. 3) The third goal was the creation of a homogenous society. The "melting pot" policy was adopted with the idea that the immigrants would be socially and culturally assimilated into the native Israeli western-style society. This meant a major cultural change for the Eastern immigrants.

The State of Israel mobilized its resources, power and imagination to achieve these goals and, indeed, the absorption process was relatively short and successful in terms of the provision of employment, housing and food and of the development of the periphery and an agricultural sector. However, it created some social and psychological problems: 1) Many of the newcomers were forced to change occupations and the human capital they acquired abroad was ignored. While the majority of them were employed in their countries of origin in 
commerce, finance, public services, or owned small businesses, here they had to switch to agriculture and industry and be employed as manual workers. Their preferences and backgrounds were not considered and the enforcement of jobs accompanied by steps taken towards cultural homogeneity led to a long-lasting crisis in family structure. 2) The centralistic absorption model led to the total dependency of immigrants on public services. 3) Many of the newcomers suffered from a severe cultural shock. The majority of them came from large cities or urban centers and in Israel were settled in isolated development towns and peripheral settlements.

It is difficult to tell whether, given the limited resources, there was a better alternative absorption model. It was probably the best policy under the difficult circumstances of that time. However, we do know that most of the development towns never took off and are socioeconomically inferior. Many of the industries created to provide employment were inefficient and were heavily subsidized in order to keep them from closing. When some of them closed it resulted in intensified unemployment; unemployment in the periphery has always reached much higher rates than the rate for the core of the state. ${ }^{21}$ A partial solution for the severe unemployment problems might be easy transportation and connection between the periphery and metropolitan areas. This can be achieved by investment in efficient transportation facilities (trains, subways, roads, etc.).

The agricultural sector gradually lost its centrality. It has been realized that Israel with its very limited land and water resources has no comparative advantage in agriculture (although it does have a comparative advantage in agricultural technology). The agricultural sector is constantly shrinking; the share of employed in agriculture which was 17.9 in 1954 dropped to

\footnotetext{
${ }^{21}$ The newspapers of the last weeks are full of sad stories of desperate unemployed heads of households in places like Ofakim, Sderto and Kiryat Malachi where unemployment reaches peaks of 20-30 percent.
} 
14.3 percent in $1963,7.5$ percent in $1973,5.5$ percent in 1983 and a mere 2.6 percent in $1996 .^{22}$

The romantic view that as time elapses social, political and economic differences between immigrants and natives will fade and all ethnic groups will blend into one homogeneous uniform society has not materialized either. Moreover, it is no more perceived as a target of the absorption policy. Ethnic diversity is being more valued rather than robbing individuals of their cultural heritage. A multicultural, pluralistic society is no more a threat but rather a benefit of immigration. ${ }^{23}$

The absorption policy adopted in the 1990s was totally different. The only objective was a smooth and efficient economic and cultural adjustment of the immigrants. There were no other political, national, cultural or economic goals. The immigrants were given free choice of settlement and occupation. The various ministries and the Bank of Israel were neutral regarding questions of spatial dispersion or preferred economic sectors, and were at the same time active in employing efficiency measures such as privatization, liberalization and exposure to import. Investments in infrastructure and education have been made accompanied by a fiscal and monetary policy in order to facilitate the huge absorption process.

As a result, the massive immigration wave was integrated successfully in a relatively short time and at a low cost. Inflation decreased (compared to the 1980s) and is at a one-digit level. Unemployment increased for a while and at its maximum reached a level of 12 percent which then decreased to 6-8 percent. Output growth has almost doubled. GDP grew in the

\footnotetext{
${ }^{22}$ A survey conducted by the CBS reveals that 25,000 agricultural farms were active in Israel in 1997, down from 32,000 in 1981 (a decrease of 22 percent); 16,000 growing fruits, 5,400 raising chickens, 2,000 raising cattle (some have more than one branch). Kibbutz farms are included in these statistics. The average annual volume of production is $\$ 70,000$ for a private farm, and $\$ 3,000,000$ for a kibbutz (Ha'aretz, December 21, 1997).

${ }^{23}$ A similar process is prevalent in the United States (Bjoras, 1990, pp. 97-99).
} 
1990-1996 period at an average annual rate of 6 percent and the output of the business sector had grown even faster, 7.4 percent per annum. This was a result of the expansion of both demand and supply of goods and services. The immigrants demanded housing, food, services and consumption goods and these market forces of demand led investors to increase their demand for investment goods in order to increase their production capacity to meet higher demand for their output. The main contributor to growth of supply was the increase in labor input. Capital growth was another contributor though of a lesser importance. ${ }^{24}$ Market forces were therefore responsible for the very positive economic performance of the Israeli economy as well as for the well being of the newcomers. ${ }^{25}$

The Soviet immigrants were well integrated socially as well, while preserving at the same time their own culture. All together, their landing in Israel is much softer than that of their counterparts of the 1950s.

The difference between the two absorption policies stems from differences in the overall conception which changed gradually and constantly from a centralistic, bureaucratic and socialist ideology in the 1950 s to a liberal one in the 1990s. From an orientation which favored enterprises owned by the Federation of Labor (Histadrut) or by large investors who had the ability to face government bureaucracy to a free market orientation which emphasizes entrepreneurship and private investment.

Although we are too close to this last wave to be able to learn the full lessons, there are already many indications that it has been a success story. The lesson that could be drawn is that a country which is facing the need to achieve a goal of absorption of a large volume of

\footnotetext{
${ }^{24}$ Gross capital stock grew at an annual rate of about 4 percent during 1990-1996.

${ }^{25}$ A survey conducted recently shows that as a result of constant increases in immigrants' income, the gap between patterns between Soviet immigrants and native Israelis is closing and expenditures, e.g., an immigrant household spends on food 1,540 shekel per month compared to 1,730 shekel spent by a native Israeli household. Differences in per capita consumption are even smaller. Gaps in other consumption items (cosmetics, footware, furniture, electrical appliances, clothing and toys) are also small (Ha'aretz, December 15, 1997).
} 
immigration, should concentrate on the successful absorption only and should not try to concurrently achieve other social or economic goals (Gabaay, Yoram, "The 1950s vis-a-vis the 1990s," Ha'aretz, October 24, 1997).

\section{The Contribution of Immigration to Economic Growth}

Neither Kuznets (1972) nor Ben-Porath (1986) were able to establish a clear-cut relationship between immigration and GDP growth rates. Ben-Porath (1986) used causality tests and concluded that in Israel causality is complex and runs in two directions: at times from population growth to economic growth and at other times the opposite is true. $\mathrm{He}$ found strong evidence for causality from immigration to economic growth in the Mandate Period (1926-1948). For the period from 1954-1982 immigration responded to the growth rate of per capita income or consumption. However, it is very clear from his study that immigration pushed the rate of increase of capital stock.

Zilberfarb (1996) analyzes the factors responsible for the impressive growth rates between 1990-1995 and argues that the main impetus for the increase in output has been the massive immigration inflow. The peace process, which gained momentum with the signing of the Oslo agreements in 1993, has helped reinforce the trend of income growth, but only to a limited extent. Following his argument, we can argue that decrease in the volume of immigration combined with the stagnation of the peace process (since the Likud Party came into power in May 1996) lead to an economic slowdown. Indeed, the growth rate in 1997 was only 2.7 percent for GDP and 0.1 percent for per capita GDP, and in 1998 these two figures continually dropped to 2.0 and -0.4 , respectively (unpublished figures - the Ministry of Finance).

The more appropriate test for causality between immigration and growth rates is, probably, to look at future growth rates using a large time lag. There is much evidence that 
when immigrants arrive in the host country their production is lower than that of the native population and it increases with residence in the country. ${ }^{26}$ If the assimilation process is spread over 20 years (which is probably an upper limit) this means that immigrants' productivity will rise in the future faster than productivity of native workers. This will lead to a future increase in GDP growth rates over a long time period. The benefits of immigration are therefore reaped in the future and accumulate for many years after the last immigrant has arrived in the country.

\section{The Importance of Language Proficiency}

Many studies conducted in Israel and other immigrant receiving countries testify to the significant role which native language acquisition has on successful economic and social integration (e.g., Chiswick, 1997; Beenstock, 1993). These studies also indicate complementarity between the native language acquisition and other forms of human capital (such as schooling). As Chiswick (1997) points out, this has important implications for the understanding of expected Hebrew language experience of the recent waves of immigrants from the former Soviet Union and Ethiopia. Intensive Hebrew language training should be very productive for the Soviet immigrants. However Hebrew language programs for Ethiopian immigrants will need to overcome their low levels of formal education and literacy. Many of the Ethiopian immigrants still live in absorption centers and this isolation from Hebrew speakers also slows their progress in acquiring Hebrew language fluency.

Israel offers immigrants free language schools for a period of six months. Not only are the courses free, but students are paid some basic subsistence allowance which allows them to

\footnotetext{
${ }^{26}$ For example, during the first year after arrival in Israel immigrants from the former USSR earned about 45 percent of the wages of native Israelis with comparable characteristics. Five years after arrival the ratio increased to 71 percent (Beenstock, M., "Immigration of the Long Run," Ha'aretz, May 1997).
} 
devote their full-time energies to the study of Hebrew. This is one of the explanations why Soviet immigrants to Israel fare better than Soviet immigrants to the US, with similar characteristics. The lesson to be learned is that immigrant-receiving countries could benefit from allocating resources to the establishment of native language schools which will significantly improve immigrants' productivity and integration.

\section{Summary and Conclusions}

This chapter presented an overview of successive immigration waves of Jews into Israel, starting in 1882 and up to the present date. The characteristics of each of the inflows have been documented including size, composition, origin, education, and professional attainments. The integration process and the effects on employment opportunities of the local native population have been examined, as well as the contribution of immigration to economic growth.

Israel provides a large, rich and varied pool of immigrants to observe. They come from a wide range of countries and have diverse educational and professional backgrounds. The Israeli experience is therefore well suited for the derivation of lessons regarding absorption policies. Some of these lessons have been outlined in the previous section in terms of comparing the different absorption policies employed by Israel, by looking into the returnmigration phenomenon which signals failure to absorb, and by relating economic growth to immigration.

Finally, we should mention that much more needs to be explored and has been omitted, due to space limitations. While we have focused on economic assimilation, we have ignored other dimensions and effects of immigration and assimilation: the demographic impact of immigration (e.g., on the age structure, fertility, internal migration, the gender balance, household formation patterns); the impact of immigration on social cohesion and ethnic 
conflicts; the effects of drastic population pressures on the environment (e.g., deterioration of natural resources such as water, open spaces or ecosystems, pollution); and the effect on micro and macro economic variables, other than employment and growth (e.g., the housing market, the balance of payment, capital stocks, consumption and savings patterns, occupational and industrial structure, unemployment, inflation, public spending and the transfer system, income distribution).

We have not paid attention to other types of immigration which, while minor compared to permanent immigration, still exist in quite sizable magnitudes. These include Arab cross border commuters from Judea, Samaria and the Gaza Strip working in the Israeli labor market since the occupation of these territories in 1967; and towards, the late 1980s, temporary labor migrants from countries such as the Philippines, Thailand, Portugal, Romania and Poland. These immigration channels are partly illegal and emerged due to deteriorating Jewish-Arab relations, making Arab workers less attractive as a form of cheap unorganized labor. It is estimated thata there are 250,000 labor migrants currently employed in the Israeli labor market, mainly in construction and agriculture.

The study of these and other subjects, all related to immigration, will be facilitated by the use of data from the recent population census conducted in 1995, and which has been released recently, as well as the panel data, derived from successive interviews of immigrants of the last wave. 


\section{References}

Abowd, John M. and Richard B. Freeman (eds.), 1991, Immigration, Trade and the Labor Market, Chicago: University of Chicago Press.

Achiram, Ephraim, 1969, "Economic Aspects of Absorption of Immigrants," The Economic Quarterly 62:151-156 (Hebrew).

Achiram, Ephraim, 1971, "Lessons from Immigration Absorption after the Six Days War," The Economic Quarterly 69-70: 61-70 (Hebrew).

Achiram, Ephraim, 1973, "Immigration, Absorption and the Israeli Economy - Past, Present, Future, The Economic Quarterly 79-80: 298-305 (Hebrew).

Amir, Shmuel, 1980, "The Wage Function of Jewish Males in Israel, between the Years 1968/69 and 1975/76," Bank of Israel Review 52: 3-14 (Hebrew).

Amir, Shmuel, 1987, "Wage Differentials between Jewish Males of Different Ethnic Origins in the 1970s," Bank of Israel Review 63: 43-63 (Hebrew).

Amir, Shmuel., 1993, "The Absorption Process of Academic Immigrants from the USSR in Israel: 1978-1984." Report of the Israeli International Institute. for Applied Economic Policy Review (Hebrew).

Bailey, Thomas R., 1987, Immigrants and Native Workers: Contrasts and Competition. Boulder, CO: Westview Press.

Beenstock, Michael, 1993, "Failure to Absorb: Return-Migration by Immigrants into Israel," Discussion Paper No. 93.04, Jerusalem: The Maurice Falk Institute for Economic Research in Israel.

Beenstock, Michael, 1993, "Learning Hebrew and Finding a Job: Econometric Analysis of Immigrant Absorption in Israel," Discussion Paper No. 93.05, Jerusalem: The Maurice Falk Institute for Economic Research in Israel.

Beenstock, Michael, 1997, "Immigration of the Long Run,” Ha'aretz, May (Hebrew).

Bein, Alex, 1976, History of the Jewish Settlement in Israel, Fifth edition, Ramat-Gan, Massada Ltd. (Hebrew).

Bein, Alex, 1982, Immigration and Settlement in the State of Israel, Jerusalem: Am Oved and the Zionist Library (Hebrew).

Ben-Porath, Yoram, 1986, "The Entwined Growth of Population and Product, 1922-1982," in Y. Ben-Porath (ed.), The Israeli Economy: Maturing Through Crisis, Cambridge: Harvard University Press. 
Blejer, Mario I. and Itshaq Goldberg, 1980, "Return Migration - Expectations versus Reality: A Case Study of Western Immigrants to Israel," Research in Population Economics 2: 433-449.

Borjas, George J., 1985, "Assimilation, Changes in Cohort Quality and the Earnings of Immigrants," Journal of Labor Economics 3(4): 463-489.

Borjas, George J., 1990, Friends or Strangers: The Impact of Immigrants on the US, New York: Basic Books.

Borjas, George J., 1994a, “The Economics of Immigration," Journal of Economic Literature 32: $1667-1717$

Borjas, George J., 1994b, “The Economic Benefits from Immigration,” NBER Working Paper No. 4955.

Card, David, 1990, "The Impact of the Mariel Boatlift on the Miami Labor Market," Industrial and Labor Relations Review 43(2): 245-257.

Chiswick, Barry R., 1978, "The Effect of Americanization on the Earnings of Foreign-Born Men," Journal of Political Economy 86(5): 897-921.

Chiswick, Barry R., 1990, "Jewish Immigrant Skill and Occupational Attainment at the Turn of the Century," Explorations in Economic History, January: 64-86.

Chiswick, Barry R., 1991a, "Soviet Jews in the United States: A Preliminary Analysis of their Linguistic and Economic Adjustment," The Economic Quarterly 148: 188-210 (Hebrew).

Chiswick, Barry R., 1991b, "Speaking, Reading and Earnings Among Low-Skilled Immigrants," Journal of Labor Economics 9(2):149-170.

Chiswick, Barry R., 1997, "Hebrew Language Usage: Determinants and Effect on Earnings Among Immigrants in Israel”, Discussion Paper No. 97.09, Jerusalem: The Maurice Falk Institute for Economic Research in Israel.

Chiswick, Barry R and Paul W. Miller, 1992, "Language in the Immigrant Labor Market." In Barry R. Chiswick (ed.), Immigration, Language and Ethnicity: Canada and the United States, Washington: American Enterprise Institute.

Chiswick, Barry R and Paul W. Miller, 1994, "Language Choice Among Immigrants in a Multi-Lingual Destination," Journal of Population Economics 7(2): 119-131.

Chiswick, Barry R and Paul W. Miller, 1995, "The Endogeneity Between Language and Earnings: International Analyses," Journal of Labor Economics 13(2): 245-287.

Cohen, Yinon, S. Bechar and R. Roujman, 1987, "Occupational Segregation in Israel, 19721983," Israel Social Science Research 5(1.2): 97-106. 
Della Pergola, Sergio, 1991, "Comment on: 'Soviet Jews in the United States: A Preliminary Analysis of their Linguistic and Economic Adjustment," The Economic Quarterly 148: 225-231 (Hebrew).

Della Pergola, Sergio, 1997, "World Jewish Population," in David Singer (ed.), American Jewish Yearbook 1997, New York: The American Jewish Committee: 513-544.

Easterlin, Richard A., 1961, "Israel's Development: Past Accomplishments and Future Problems," Quarterly Journal of Economics 75: 63-86.

Eban, Abba, 1972, My Country: The Story of Modern Israel, Jerusalem: Weidenfeld and Nicolson and Tel-Aviv: Davar.

Eckstein, Zvi and Yoram Weiss, 1997, “The Absorption of Highly Skilled Immigrants: Israel: 1991-1995." Paper presented at the CEPR conference "European Migration: What Do We Know?" Munich, November.

Eisenstadt, Shmuel N., 1967, Israeli Society, London: Weidenfeld and Nicholson.

Eisenstadt, Shmuel N., 1973, Israeli Society: Background, Development, Problems, Jerusalem: Magnes Press, Hebrew University of Jerusalem.

Eliav, M., 1978, Eretz Yisrael and its Yishuv in the 19th Century, 1917-1977, Jerusalem: Keter Publishing House (Hebrew).

Elizur, Dov, 1980, "Israelis in the United States: Motives, Attitudes and Intentions," American Jewish Year Book, Philadelphia: Jewish Publication Society of American: 5367.

Freidberg, Rachel M., 1995, "You Can't Take it with You? Immigrant Assimilation and the Portability of Human Capital: Evidence from Israel," Discussion Paper No. 95.02, Jerusalem: The Maurice Falk Institute for Economic Research in Israel.

Gaathon, A.L., 1964a, "Economic Growth in Israel: 1948-1953", The Economic Quarterly 43: 13-30 (Hebrew).

Gaathon, A.L., 1964b, "Economic Growth in Israel: 1954-1962", The Economic Quarterly 43: 205-216 (Hebrew).

Green, David A., 1995, "Immigrant Occupational Attainment: Assimilation and Mobility over Time," Discussion Paper No. 95-15, Department of Economics, The University of British Columbia, Vancouver, Canada.

Gross, Nachum T., 1996, "Israeli Economic Policies, 1948-1951, Problems of Evaluation," The Journal of Economic History 50(1): 67-83.

Ha'aretz, daily newspaper, various issues (Hebrew). 
Halevi, Nadav and Ruth Klinov-Malul, 1968, The Economic Development of Israel, Jerusalem: Academon (Hebrew).

Hercowitz, Zvi and Leora Meridor, 1991, "The Macroeconomic Effects of Mass Immigration to Israel," Working Paper No. 29-91, The Foerder Institute for Economic Research, TelAviv University.

Hercowitz, Zvi and Eran Yahsiv, 1997, "The Effects of Mass Immigration on the Employment of Natives," Discussion Paper No. 5-97, Tel-Aviv University: The Pinhas Sapir Center for Development.

International Monetary Fund, 1997, World Economic Outlook, New York.

Israel, Central Bureau of Statistics, Annual Statistical Abstract, various issues.

Israel, Central Bureau of Statistics, 1970, Immigration Absorption Survey (conducted jointly with the Ministry of Absorption and the Institute for Applied Social Research).

Israel, Ministry of Labor, The Labor Market in Israel in Recent Months, various issues.

Jasso, Guillermina and Mark R. Rosenzweig, 1982, "Estimating the Emigration Rates of Legal Immigrants using Administrative Survey Data: The 1971 Cohort of Immigrants to the United States," Demography 19: 279-290.

Jones, C. and A.D. Smith, 1970, The Economic Impact of Commonwealth Immigration, Cambridge: CUP.

Katz, Yossi and Shoshana Neuman, 1996, "Women's Quest for Occupational Equality: The Case of Agricultural Workers in Pre-State Israel," Rural History: Economy, Society, Culture 7(1): 32-52.

Keren-Ha'yesod, 1953, in Numbers - A Periodical for Statistics and Information 46 (Hebrew).

Kuznets, Simon, 1972, "The Gap: Concept, Measurement, Trends," in Gustav Ranis (ed.), The Gap Between Poor and Rich Nations, London: Macmillan.

Kuznets, Simon, 1973, "Notes on the Economic Development of Israel," The Economic Quarterly 78-79: 189-209 (Hebrew).

LaLonde, Robert and Robert Topel, 1991, "Immigrants in the American Labor Market: Quality, Assimilation and Distributional Effects," American Economic Review 81: 297302.

Lamdani, R., 1989, "Emigration from Israel," in Y. Ben-Porath (ed.), The Israeli Economy: Maturing Through Crisis, Tel-Aviv: Am-Oved (Hebrew)..

Lee, Everett, S., 1966, “A Theory of Migration,” Demography: 47-57. 
Licht, G. and V. Steiner, 1993, "Assimilation, Labor Market Experience and Earnings Profiles of Temporary and Permanent Immigrant Workers in German," Zentrum für Europäische Wirtschatsforschung GmbH, Discussion Paper No. 93-06, Mannheim (February).

Lifschitz, Chen, Gila Noam and Eran Segal, 1993, "A Survey of Young Ethiopian Immigrants", Jerusalem: JDC-Brookdale Institute of Gerontology and Human Development.

Lifschitz, Chen, Gila Noam and Eran Segal, 1997, "The Absorption of Ethiopian Immigrant Youth - A Multi-Dimensional Perspective, Research Report: RR-313-97, Jerusalem: JDC-Brookdale Institute of Gerontology and Human Development.

Lipshitz, Gabriel, 1991, "Immigration and Internal Migration as a Mechanism of Polarization and Dispersion of Population and Development: The Israeli Case," Economic Development and Cultural Change, 391-408.

Lipshitz, Gabriel, 1997, "Immigrants from the Former Soviet Union in the Israeli Housing Market: Spatial Aspects of Supply and Demand," Urban Studies 34(3): 471-488.

Metzer, Jacob, 1982, "Fiscal Incidence and Resource Transfer between Jews and Arabs in Mandatory Palestine," Research in Economic History 7: 87-132.

Naor, M. (ed.), 1986, Immigrants and Settlements (Ma'abarot): 1948-1952, Jerusalem: Yad BenTzvi (Hebrew).

Neuman, Shoshana, 1994, "Ethnic Occupational Segregation in Israel," Research on Economic Inequality 5: 125-151.

Neuman, Shoshana and Ronald Oaxaca, 1998, "Estimating Labor Market Discrimination with Selectivity Corrected Wage Equations: Methodological Considerations and an Illustration from Israel," CEPR, Discussion Paper No. 1915.

Neuman, Shoshana and Jacques G. Silber, 1996, "Wage Discrimination Across Ethnic Groups: Evidence from Israel," Economic Inquiry 34(4): 648-661.

Ofer, Gur, A. Vinokur and Y. Bar-Chaim, 1980, "Absorption in Israel and Economic Contribution of Immigrants from the Soviet Union," Jerusalem: The Maurice Falk Institute for Economic Research (Hebrew).

Patinkin, Don, 1959, The Israeli Economy: The First Decade, Jerusalem: Falk Project for Economic Research.

Prop, P., 1968, “Twenty Years of Employment Policy,” The Economic Quarterly 57-58: 7285 (Hebrew).

Rabi, C., 1968, “Demographic Development of Israel: 1948-1968," The Economic Quarterly 57-58: 43-54 (Hebrew). 
Ramos, F.A., 1992, "Out-Migration and Return Migration of Puerto Ricans," in G.J. Borjas and R.B. Freeman (eds.), Immigration and the Workforce, Chicago: University of Chicago Press.

Sicron, Moshe, 1957, Immigration to Israel, 1949-1953, Jerusalem: Falk Project for Economic Research and Central Bureau of Statistics.

Simon, Julian L., 1976, "Economic Implications of Russian Immigration," The Economic Quarterly 90: 244-253 (Hebrew).

Steiner, V. and J. Velling, 1992, "Re-Migration behavior and Expected Duration of Stay of Guest-Workers in Germany," Zentrum für Europäische Wirtschatsforschung GmbH, Discussion Paper No. 92-14, Mannheim (November).

Tunali, I., 1986, "A General Structure for Models of Double-Selection and an Application to a Joint Migration/Earnings Process with Remigration," Research in Labor Economics 8 (Pt.B): 235-282.

World Bank, 1995, Word Tables, Baltimore: The Johns Hopkins University Press.

United Nations, 1970, Yearbook of National Accounts Statistics, Vol. II: International Tables, New York.

Zilberfarb, Ben-Zion, 1996, "The Israeli Economy in the 1990s: Immigration, the Peace Process and Medium-Term Prospects for Growth," Israel Affairs 3(1): 1-13.

Zimmerman, Klaus, F., 1995, "Tackling the European Migration Problem," Journal of Economic Perspectives 9(2): 45-62. 
Table 1

Waves of Jewish Immigration - 1882-1998

\begin{tabular}{|c|c|c|c|c|}
\hline Period & $\begin{array}{l}\text { Jewish Population } \\
\text { at beginning of } \\
\text { period }\end{array}$ & $\begin{array}{l}\text { Number of } \\
\text { Jewish } \\
\text { immigrants }\end{array}$ & $\begin{array}{l}\text { Number of } \\
\text { immigrants per } \\
\text { year }\end{array}$ & $\begin{array}{l}\text { Annual population } \\
\text { growth rate stemming } \\
\text { from immigration only }\end{array}$ \\
\hline $1882-14 / 5 / 1948$ & 24,000 & 542,857 & 8,293 & 4.9 \\
\hline $15 / 5 / 1948-1951$ & 649,500 & 687,624 & 194,244 & 22.6 \\
\hline $1952-1966$ & $1,404,400$ & 587,472 & 39,165 & 2.4 \\
\hline $1967-1989$ & $2,344,900$ & 558,909 & 24,300 & 0.9 \\
\hline $1990-1998$ & $3,717,100$ & 879,486 & 97,721 & 2.4 \\
\hline
\end{tabular}

Calculations based on: Annual Statistical Abstracts, various issues;

The Labor Market in Israel in Recent Months, various issues. 
Table 2

Sources of Population Growth: Jewish and Non-Jewish Population 15/5/1948 - 1996

\begin{tabular}{|c|c|c|c|c|c|c|c|c|}
\hline Period & $\begin{array}{l}\text { Population } \\
\text { at } \\
\text { beginning } \\
\text { of period }\end{array}$ & $\begin{array}{l}\text { Natural } \\
\text { increase }\end{array}$ & Migr & n balance & $\begin{array}{c}\text { Total } \\
\text { growth }\end{array}$ & $\begin{array}{l}\text { Population at } \\
\text { end of period }\end{array}$ & $\begin{array}{l}\text { Annual } \\
\text { growth rate }\end{array}$ & $\begin{array}{l}\text { Percent of immigration balance } \\
\text { out of total growth }\end{array}$ \\
\hline \multicolumn{9}{|c|}{ Total Immigrants } \\
\hline \multicolumn{9}{|c|}{ Jewish Population } \\
\hline 15/5/1948-1996 & 649.6 & 2022.3 & 1988.0 & 2590.4 & 4011.2 & $4637.4^{1}$ & 4.1 & 49.6 \\
\hline 15/5/1948-1951 & 649.6 & 88.4 & 668.4 & 687.6 & 754.8 & 1404.4 & 23.7 & 88.3 \\
\hline $1952-1966$ & 1404.4 & 546.7 & 432.5 & 587.5 & 979.2 & 2344.9 & 3.5 & 46.0 \\
\hline $1967-1989$ & 2344.9 & 1042.3 & 314.5 & 558.9 & 1356.8 & 3717.1 & 2.0 & 22.9 \\
\hline 1990-1996 & 3717.1 & 344.9 & 575.4 & 756.4 & 920.3 & 4637.4 & 3.2 & 62.5 \\
\hline \multicolumn{9}{|c|}{ Non-Jewish Population } \\
\hline 15/5/1948-1996 & 156.0 & 815.2 & 81.9 & 84.7 & 897.1 & $1122.0^{1}$ & 4.3 & 9.1 \\
\hline
\end{tabular}

1. Including census adjustments. The non-Jewish population includes the addition of the Arab population in East Jerusalem and in the Golan.

Source: Annual Statistical Abstracts, various issues. 
Table 3

Jewish Immigration Waves: 1882 - May 1948

\begin{tabular}{|l|c|}
\hline \multicolumn{1}{|c|}{ Waves of Aliyah (immigration) } & Volume (thousands) \\
\hline First Aliyah (1882-1903) & $20-30$ \\
Second Aliyah (1904-1914) & $35-45$ \\
Third Aliyah (1919-1923) & 35 \\
Fourth Aliyah (1932-1938) & 82 \\
Fifth Aliyah (1924-1931) & 217 \\
World War II (1939-1945) & 92 \\
Post-World War II (1947- May 1948) & 61 \\
Total (1882 - May 1948) & $542-562$ \\
\hline
\end{tabular}

Source: Sircon, M., Immigration to Israel: 1948-1953, Jerusalem: The Falk Center for Economic Research in Israel and the Central Bureau of Statistics, 1957, p. 14, table 1.

Table 4

Years of Schooling: Soviet Immigrants and the Israeli Jewish Population, 1978

\begin{tabular}{|l|c|c|c|c|c|c|}
\hline \multicolumn{2}{|c|}{ Years of schooling } & \multicolumn{3}{|c|}{ Soviet immigrants } & \multicolumn{3}{c|}{ Israeli population } \\
\hline 0 & Men & Women & Total & Men & Women & Total \\
$1-4$ & - & 0.2 & 0.1 & 3.9 & 9.1 & 6.6 \\
$5-8$ & 3.6 & 4.7 & 4.2 & 3.9 & 4.4 & 4.1 \\
$9-12$ & 12.8 & 11.1 & 11.9 & 23.1 & 22.4 & 22.7 \\
$13-15$ & 27.8 & 31.1 & 29.5 & 47.9 & 45.1 & 46.5 \\
$16+$ & 28.9 & 32.7 & 30.8 & 10.5 & 13.1 & 11.8 \\
\hline
\end{tabular}

Sources: Annual Statistical Abstract, 1979, p. 618/9

Survey conducted by the Central Bureau of Statistics, 1979, in Ofer, Vinokur and Bar-Chaim (1980). 
Table 5

Occupational Distribution:

Soviet Immigrants and the Local Jewish Population

\begin{tabular}{|l|c|c|c|c|}
\hline & \multicolumn{2}{|c|}{$\begin{array}{c}\text { Soviet Immigrants } \\
\text { (1970-1979) }\end{array}$} & \multicolumn{2}{c|}{$\begin{array}{c}\text { Israeli Population } \\
\text { (1977) }\end{array}$} \\
Occupation & Men & Women & Men & Women \\
\hline Academic and Scientific Occupations & 29.8 & 30.0 & 7.8 & 7.5 \\
Technological Occupations & 14.6 & 24.2 & 8.6 & 22.5 \\
Managers and Clerical Workers & 3.9 & 16.4 & 19.8 & 31.9 \\
Sales Workers & 5.0 & 5.4 & 8.3 & 6.9 \\
Service Workers & 2.1 & 5.0 & 7.6 & 18.2 \\
Agricultural Workers & 0.1 & 0.1 & 6.1 & 2.9 \\
Skilled Industrial Workers and Other Workers & 44.5 & 18.9 & 41.6 & 10.1 \\
\hline
\end{tabular}

Source: Ofer, Vinokur and Bar-Chaim, tables 10 and 11.

Table 6

Occupation and Schooling of Israeli Workers (1990) and Immigrants ${ }^{1}$ (percent)

\begin{tabular}{|l|ccc|c|c|c|}
\hline & \multicolumn{3}{|c|}{ Occupation $^{2}$} & \multicolumn{3}{c|}{ Schooling } \\
\cline { 2 - 7 } & 1 & 2 & 3 & $0-12$ & $13-15$ & $16+$ \\
\hline Israeli Workers & 14.8 & 18.1 & 67.1 & 74.8 & 14.5 & 10.7 \\
Immigrants in USSR & 35.5 & 32.6 & 35.6 & 47.3 & 41.4 & 11.3 \\
\hline
\end{tabular}

1. Occupation in USSR and education of immigrants is according to the distribution among those who arrived in 1991. Occupation of immigrants in Israel is according to the average distribution in 1991-1995 for those who arrived in 1990-1991 (Source: CBS Income Surveys, 1991-1995).

2. Occupation 1 includes engineers, physicians, professors, other professionals with an academic degree and managers; Occupation 2 includes teachers, technicians, nurses, artists and other professionals; Occupation 3 includes blue collar and unskilled workers.

Source: Eckstein, Zvi and Yoram Weiss, 1997, “The Absorption of Highly Skilled Immigrants: Israel 1991-1995," p.41, table 2. 
Table 7

Growth Rates of Product and Population

\begin{tabular}{|l|c|c|c|c|}
\hline Year & $\begin{array}{l}\text { Annual Growth } \\
\text { Rate of GDP } \\
\text { Rate of Per Capita } \\
\text { GDP }\end{array}$ & $\begin{array}{l}\text { Annual Growth } \\
\text { of Per Capita } \\
\text { Personal } \\
\text { Consumption }\end{array}$ & $\begin{array}{l}\text { Annual Growth } \\
\text { Rate of Jewish } \\
\text { Population }\end{array}$ \\
\hline $\mathbf{1 9 2 2 - 1 9 3 2}$ & 17.6 & 7.8 & - & 8.0 \\
\hline $\mathbf{1 9 3 2}-\mathbf{1 4 / 5 / 4 8}$ & 11.2 & 3.0 & - & 8.4 \\
\hline $\mathbf{1 5 / 5 / 4 8 - 1 9 5 0}$ & - & - & 3.8 & 26.5 \\
\hline $\mathbf{1 9 5 1}$ & 30.1 & 10.3 & 5.3 & 3.3 \\
\hline $\mathbf{1 9 5 2 - 6 6}$ & 10.3 & 6.2 & -0.9 & 1,7 \\
\hline $\mathbf{1 9 6 7}$ & 2.3 & -1.0 & 4.7 & 2.9 \\
\hline $\mathbf{1 9 6 8 - 1 9 7 2}$ & 11.9 & 8.5 & 1.5 & 2.2 \\
\hline $\mathbf{1 9 7 3 - 1 9 8 0}$ & 3.1 & 0.9 & 2.5 & 1.4 \\
\hline $\mathbf{1 9 8 1 - 1 9 8 9}$ & 2.7 & 1.1 & 2.3 & 6.2 \\
\hline $\mathbf{1 9 9 0}$ & 6.1 & 2.8 & 1.0 & 5.0 \\
\hline $\mathbf{1 9 9 1}$ & 6.3 & 0.1 & 4.1 & 2.4 \\
\hline $\mathbf{1 9 9 2}$ & 6.6 & 2.9 & 4.5 & 2.2 \\
\hline $\mathbf{1 9 9 3}$ & 3.5 & 0.8 & 6.4 & 2.4 \\
\hline $\mathbf{1 9 9 4}$ & 6.8 & 4.0 & 4.4 & 2.4 \\
\hline $\mathbf{1 9 9 5}$ & 7.1 & 4.3 & 2.6 & 2.4 \\
\hline $\mathbf{1 9 9 6}$ & 4.7 & 2.5 & 1.6 & 2.5 \\
\hline $\mathbf{1 9 9 7}$ & 2.7 & 0.1 & 0.9 & 2.4 \\
\hline $\mathbf{1 9 9 8}$ & 2.0 & -0.4 & & \\
\hline
\end{tabular}

Sources: Ben-Porath (1986) for 1922-1950.

Calculations based on Annual Statistical Abstracts, various issues for 1951-1996.

Unpublished figures- The Ministry of Finance for 1997/8.

Table 8

Growth Rates - Various Countries, 1950-1968

\begin{tabular}{|l|c|c|c|}
\hline \multicolumn{1}{|c|}{ Country } & GDP & Population & GDP per capita \\
\hline \hline \multirow{2}{*}{ Israel } & 9.2 & 3.9 & 5.1 \\
Japan & 9.7 & 1.0 & 8.6 \\
Taiwan & 8.5 & 3.4 & 4.9 \\
South Korea & 6.3 & 2.7 & 3.5 \\
Austria & 5.2 & 0.4 & 4.8 \\
Germany & 6.2 & 1.1 & 5.0 \\
France & 5.1 & 1.2 & 3.9 \\
Italy & 5.6 & 0.7 & 4.9 \\
Greece & 6.4 & 0.8 & 5.6 \\
Spain & 6.1 & 1.0 & 5.1 \\
Portugal & 5.4 & 0.8 & 4.6 \\
Puerto Rico & 6.3 & 1.1 & 5.1 \\
\hline \hline
\end{tabular}

Sources: Kuznets, S., 1973, "Notes on the Economic Development of Israel," The Economic Quarterly: Yearbook of National Accounts Statistics, 1970,Vol. II: International Tables, tables 4A and 4B, New York. 